CARRA Working Paper Series

Working Paper Series \#2015 - 02

\title{
Assimilation and Coverage of the Foreign-Born Population in Administrative Records
}

\author{
Renuka Bhaskar \\ U.S. Census Bureau \\ Leticia Fernandez \\ U.S. Census Bureau \\ Sonya Rastogi \\ U.S. Census Bureau \\ Center for Administrative Records Research and Applications \\ U.S. Census Bureau \\ Washington, D.C. 20233
}

Paper Issued: April 21, 2015

Disclaimer: This paper is released to inform interested parties of research and to encourage discussion. The views expressed are those of the authors and not necessarily those of the U.S. Census Bureau. 


\title{
Assimilation and Coverage of the Foreign-Born Population in Administrative Records
}

Renuka Bhaskar, Leticia Fernandez, and Sonya Rastogi

U.S. Census Bureau

\begin{abstract}
The U.S. Census Bureau is researching ways to incorporate administrative data in decennial census and survey operations. Critical to this work is an understanding of the coverage of the population by administrative records. Using federal and third party administrative data linked to the American Community Survey (ACS), we evaluate the extent to which administrative records provide data on foreign-born individuals in the ACS and employ multinomial logistic regression techniques to evaluate characteristics of those who are in administrative records relative to those who are not. We find that overall, administrative records provide high coverage of foreign-born individuals in our sample for whom a match can be determined. The odds of being in administrative records are found to be tied to the processes of immigrant assimilation naturalization, higher English proficiency, educational attainment, and full-time employment are associated with greater odds of being in administrative records. These findings suggest that as immigrants adapt and integrate into U.S. society, they are more likely to be involved in government and commercial processes and programs for which we are including data. We further explore administrative records coverage for the two largest race/ethnic groups in our sample - Hispanic and non-Hispanic single-race Asian foreign born, finding again that characteristics related to assimilation are associated with administrative records coverage for both groups. However, we observe that neighborhood context impacts Hispanics and Asians differently.
\end{abstract}

Keywords: Foreign Born, Administrative Records, American Community Survey, Record Linkage 


\section{Introduction}

Administrative records are data collected by federal and state governments in the course of providing services and administering laws such as the tax code, as well as data collected and compiled by third parties for purposes such as marketing analytics. In the current environment of budget constraints and declining respondent cooperation, administrative records can be a costeffective way to supplement or even replace data collection efforts. For example, administrative records can be used to update and supplement survey frames, inform edit and imputation routines, and construct new estimates. Since administrative records are not typically collected for statistical purposes, however, there may be challenges regarding data quality and coverage of particular populations.

In this study, we examine administrative records coverage of the U.S. immigrant population, which is not only diverse in terms of its demographic and socioeconomic characteristics, but also includes hard-to-reach subpopulations (Grieco et al. 2012; Massey and Capoferro 2004; Moohn 2012). Research that utilizes administrative records to study the foreign-born population largely focuses on wages and employment (Brojas and Tienda 1993), measuring immigration and emigration flows (Duleep and Dowhan 2008; Jasso and Rosenzweig 1982; Schwabash 2011), and producing estimates of the unauthorized population (Hill and Johnson 2011; Hoefer et al. 2010). Much of the research utilizes administrative records from the Department of Homeland Security (DHS) and in previous years from the Immigration and Naturalization Services. However, little is known about the extent to which administrative records that are not from DHS accurately reflect the foreign-born population.

This paper expands the literature on administrative records coverage of the foreign born. We ask two main questions: 1) to what extent do administrative records from non-DHS sources provide data on the foreign born and 2) what characteristics are associated with this coverage. We hypothesize that coverage is associated with the process of assimilation, the gradual and multidimensional process through which immigrants and their offspring adapt, integrate, and participate in their host society. We link individual records from the 2006-2010 American Community Survey (ACS) to a compilation of federal and third party administrative records and compare the characteristics of foreign-born individuals who are not found in administrative records to those who are.

Our findings suggest that the administrative records used in this study provide high coverage of foreign-born individuals in the ACS who have received a unique person identifier via our record linkage system, though there is variation in coverage by characteristics. We find more variation in the assignment of unique identifiers which are required to determine matches to administrative records. As we expected, many of the same factors that relate to assimilation processes are also indicators of whether or not foreign-born individuals are assigned unique identifiers and present in administrative records. These findings are important as the Census Bureau continues to evaluate the use of administrative records for data collection and population measurement operations and will assist in determining future areas of research and data acquisition to improve coverage. 


\section{Literature Review}

Two Census Bureau studies evaluate coverage of persons in the 2010 Census and 2010 ACS by the same administrative records we use in our analysis (Luque and Bhaskar 2014; Rastogi and O’Hara 2012). These studies evaluate coverage by race, Hispanic origin, age, and sex as well as geographic and housing factors. However, these evaluations do not include analyses by citizenship or place of birth. Another Census Bureau study evaluates the bias in the assignment of unique identifiers that are required to determine administrative records coverage (Bond et al. 2014). This work includes analyses of citizenship status, finding lower rates of assignment of unique identifiers for non-citizens in the ACS compared to natives and naturalized U.S. citizens. Bond et al. (2014) also compare results for the 2009 and 2010 ACS and find that record linkage methodological enhancements for 2010 result in diminished biases in the assignment of unique identifiers by many factors including citizenship status.

These studies provide an important baseline in understanding administrative records coverage of individuals in Census Bureau data but do not assess coverage of foreign-born individuals specifically. For example, they do not evaluate match rates to administrative records for the foreign born or evaluate the assignment of unique identifiers for foreign-born individuals by characteristics other than citizenship status. The goal of our paper is to better understand administrative records coverage of the foreign-born population - both in terms of the assignment of unique identifiers and match rates to the administrative records used in this study. Moreover, we assess how coverage varies by characteristics among foreign-born individuals. We frame our hypotheses of how characteristics may be associated with administrative records coverage around assimilation theories.

Classic assimilation theory posits that immigrant groups become more similar to mainstream society demographically, economically, and culturally over time (Brown and Bean 2006; Gordon 1964). For instance, this theory suggests that immigrants that have been in a society longer, as well as their offspring, will be more integrated into the host society relative to new immigrants (Brown and Bean 2006). Measures of assimilation include language, socioeconomic status, residential patterns and spatial concentration, and intermarriage (Waters and Jimenez 2005). The theory, formulated based on the experience of European immigrants who immigrated in the early 1900 s to the United States, assumes straight-line assimilation or convergence of immigrants into the host society (Brown and Bean 2006; Gordon 1964).

Other researchers argue that immigrant groups follow varied paths towards assimilation. Segmented assimilation theory, proposed as a counter to classic assimilation theory, posits that structural barriers can deter assimilation, resulting in stagnant and declining chances for socioeconomic mobility for some immigrants and their children, while others achieve upward assimilation (Portes and Zhou 1993; Portes et al. 2005). Specifically, the human capital that immigrants bring and the reception they encounter in the host country likely influence their respective social and economic assimilation trajectories (Haller et al. 2011). Lee and Zhou (2013) suggest that interethnic variations in the pathways to socioeconomic assimilation arise from the interplay of immigrants' understanding of how the world works ("frames" that delineate possibilities), and their access to tangible and intangible resources in co-ethnic communities facilitates or prevents immigrants from reaching such possibilities. 
Using these theoretical frameworks, we hypothesize that factors influencing immigrant assimilation affect integration into government programs and third party data. In other words, we expect that assimilation is positively associated with being in administrative records. In the following sections, we discuss literature on various aspects of assimilation and describe how we expect these factors relate to administrative records coverage.

\section{Years in the United States, Citizenship and English Language Proficiency}

Assimilation is a gradual process tied to length of time in the host country - individuals who have lived in the United States longer have had more time to integrate into American culture. Gaining citizenship may also be an indicator of assimilation and we expect these characteristics to be associated with higher likelihoods of being in administrative records.

Individuals who have lived in the United States for a longer period of time as well as those who have become naturalized may be more likely to own a home (Kochar et al. 2009; Trevelyan et al. 2013), have higher paying jobs (Shierholz 2010), and, for female immigrants in particular, be more attached to the labor force (Kandel 2011). ${ }^{1}$ As a result, they may be more likely to be in tax data or third party data reflecting utility payments, property tax records, and mortgage applications compared to the newly arrived. In addition, both citizenship status and length of time living in the United States are factors that affect eligibility for government assistance programs, such as Supplemental Security Income (SSI) and Temporary Assistance for Needy Families (TANF) - both programs for which data are included in our analysis (Broder and Blazer 2011; Fortuny and Chaudry 2011).

English language proficiency, an important aspect of assimilation, may also be correlated with attachment to the labor force and access to higher paying jobs, resulting in a greater likelihood of being in the administrative records used in our analysis. Furthermore, among eligible lowincome foreign-born individuals, those with higher English proficiency may be better able to navigate federal programs.

\section{Socioeconomic Status}

Along with language proficiency, we expect socioeconomic factors such as education, income and labor force participation influence the likelihood of being in administrative records. Higher levels of education may increase the likelihood of being in administrative records for several reasons. First, education may facilitate the navigation of government programs. Higher levels of education may also be associated with stronger ties to the labor market and to higher incomes, resulting in being present in federal records such as tax data and also third party data such as credit bureau header or property tax data.

The inclusion of administrative data from government benefit programs with specific income eligibility requirements may increase coverage of lower income populations. Still, while the foreign-born population is more likely to have lower incomes than the native population,

\footnotetext{
${ }^{1}$ For female immigrants, labor force participation increases with time in the United States and naturalization. Noncitizen males, on the other than, have higher rates of labor force participation relative to naturalized males (Kandel 2011).
} 
research has shown that the foreign born have lower rates of benefit use (Capps and Fortuny 2006; Capps et al. 2004; Fix and Passel 2002; Friedberg and Jaeger 2009; Hernandez 2004). This lower rate of benefit use is due in part to eligibility requirements as well as lower rates of use even when eligible (Capps and Fortuny 2006). As a result, lower income may not translate into coverage in administrative records through participation in benefit programs.

We generally expect that labor force participants are more likely to be in our administrative records universe than non-participants, however there may be differences based on the type of employment. Workers in informal jobs may be less likely to appear in administrative data compared to those in formal positions that are more likely to require government paperwork.

Whether employment is full time versus part time or seasonal work may also impact the likelihood of being in the administrative data in our study. For example, research on migrant seasonal farmworkers suggests this population faces barriers to accessing government provided needs-based services (Villarejo 2003; Quandt et al. 2004). Thus, seasonal and part-time workers in farm-related occupations may be less likely to be in administrative data than those who work full time throughout the year.

\section{Neighborhood Context}

Segmented assimilation theory discusses the importance of neighborhood characteristics, such as access to resources and presence of co-ethnic communities in the assimilation process (Portes et al. 2005). Depending on their level of tangible and intangible resources, neighborhoods with a high concentration of co-ethnics may offer recent immigrants access to already established networks that provide important information about housing, schools, local clinics and other basic needs (Hagan 1998; Toussaint-Comeau 2012). Moreover, depending on the level of economic development and entrepreneurship, employment and self-employment opportunities within immigrant enclaves may be more attractive than available jobs elsewhere (Toussaint-Comeau 2012; Wilson and Portes 1980). It is plausible, then, that immigrants residing in enclaves may come to adapt and interact faster with mainstream society than similar immigrants living elsewhere, and this may increase their likelihood of being in the administrative records used in this study.

However, some studies report that immigrants who restrict their social and employment associations to co-ethnics risk missing out on job and earnings opportunities (Parks 2004; Sanders and Nee 1987; Xie and Gough 2011). To the extent that these individuals also limit their interactions with other areas of mainstream society, this suggests that immigrants residing in neighborhoods with a high presence of co-ethnics may not be found in administrative records. For example, a study of low-income immigrant women in Los Angeles finds higher rates of unemployment for Mexican and Vietnamese women residing in ethnic enclaves compared to those living in less segregated neighborhoods (Parks 2004). If living in ethnic enclaves is tied, as this study finds, to higher rates of unemployment, we would expect to find lower rates of administrative records coverage for people living in these areas. 
Neighborhood characteristics may also influence foreign-born participation in assistance programs. For example, research on disability program participation finds that networks have a role in immigrant take-up - specifically immigrants living in areas with a high concentration of co-ethnics are more likely to receive disability payments when others in their ethnic group have higher take-up rates (Furtado and Theodoropoulos 2012).

\section{Demographic Characteristics}

Race and ethnicity may play a role in the assimilation process as well. Immigrant groups that experience race and ethnic discrimination face barriers to assimilating (Brown and Bean 2006). Recent research indicates continued socioeconomic disparities among immigrants from different countries of birth and by race and Hispanic origin (Grieco et al. 2012). These findings reinforce the argument that attitudes and perceptions about particular racial and ethnic minorities in the host country influence whether immigrants find a favorable reception from authorities and society in general to assimilate successfully (Portes and Rumbaut 2006).

Immigrants from different regions tend to arrive with particular socioeconomic characteristics. Asian immigrants, on average, tend to come from high socioeconomic backgrounds that facilitate the formation of strong middle-class co-ethnic communities in the United States (Lee and Zhou 2013). Because of the higher socioeconomic backgrounds of many Asian immigrants, those who arrive with lower levels of human capital and poor socioeconomic backgrounds may be able to circumvent these initial circumstances for themselves and their children because of their access to ethnic or pan-ethnic capital (Lee and Zhou 2013, 2014). Strong co-ethnic communities can provide not only examples of successful co-ethnics who may be viewed as a reference for immigrants to measure their and their children's progress, but also the resources to facilitate socioeconomic mobility (Zhou 2009).

In contrast, as a group, Hispanic immigrants tend to arrive with low levels of education, poor socioeconomic backgrounds and disadvantaged circumstances (Menjívar 2008). The lack of comparable co-ethnic resources, together with a negative reception by both the authorities and the host society in general are likely to limit further their and their children's paths to socioeconomic mobility (Menjívar 2008; Portes and Rumbaut 2006).

\section{Data and Methods}

This paper uses data from the 2006-2010 American Community Survey (ACS) and multiple administrative records sources. The ACS is a nationally representative stratified ongoing survey that samples from approximately 295,000 households every month (about 3.5 million households per year). ${ }^{2}$ The survey includes questions on a variety of demographic, socioeconomic, and household items. Individual and tract-level characteristics used in this analysis are derived primarily from the 2006-2010 ACS data. Additional data from the 2010 Census are used to estimate county population size.

\footnotetext{
${ }^{2}$ For more information on the ACS, see U.S. Census Bureau (2014).
} 
Administrative records from federal agencies and third party vendors are used in this study. Federal data come from Individual Income Tax Returns (IRS 1040) and Information Returns (IRS 1099); ${ }^{3}$ data from the Department of Housing and Urban Development on people who receive housing or rental assistance or applied for federally-insured mortgages; Social Security Administration Supplemental Security Record data on those who receive SSI; Centers for Medicare and Medicaid Services Medicare enrollee data; the Indian Health Service Patient Registration File; and, data on TANF participants. ${ }^{4}$

Third party data obtained from five vendors are aggregated from a variety of sources including credit bureau header information, utility records, white pages, magazine/periodical change of address information, property taxes, and voter registration rolls.

Unique person identifiers are used to match persons in the 2006-2010 ACS to persons in each of the administrative record sources listed above. These identifiers, called protected identification keys (PIKs), are assigned to both the 2006-2010 ACS and administrative records data using matching software known as the Person Identification Validation System (PVS) (Wagner and Layne 2014). Following the PVS process, all personal identifiers are removed to anonymize the data and preserve confidentiality in the research files used for statistical purposes.

To evaluate the extent of coverage provided by administrative records, we calculate the percent of individuals who match to each administrative records file. The universe for this analysis includes unweighted respondents in the 2006-2010 ACS whose response to the citizenship question was not allocated. ${ }^{5}$ The focus of our paper is on foreign-born individuals, i.e. those whose reported citizenship status is non U.S. citizens or naturalized U.S. citizens. We also show selected results for native individuals for comparison.

To address our second research question regarding the characteristics associated with coverage in administrative records, we evaluate rates of PIK assignment and matching to administrative records among the foreign born by various characteristics. We then use multinomial regression techniques to evaluate the relationships between indicators of assimilation and coverage in administrative records. One model includes all foreign-born individuals in our sample and two additional models evaluate separately administrative records coverage for the two largest racial/ethnic groups in our sample - Hispanic foreign born and non-Hispanic single race Asian foreign born. The dependent variable in each of these regressions is coded into three categories: a) no PIK assigned, b) PIK assigned but does not match to administrative records, and c) PIK assigned and does match to administrative records. Our models predict the likelihood of being in the first two groups compared to our base category of having a PIK assigned that does match to

\footnotetext{
${ }^{3}$ Information returns data are based on the following forms: W-2, 1099-S, SSA-1099, 1099-G, 1099-DIV, 1099INT, 1099-MISC, and 1099-R.

${ }^{4}$ The administrative records data used in this analysis are the same as those used in the U.S. Census Bureau's "2010 Census Match Study”. For more information on these data sets, see Rastogi and O'Hara (2012)

${ }^{5}$ In cases where an ACS respondent does not provide a response for a particular demographic variable, or the reported response was incomplete or invalid, the Census Bureau has to allocate the response. For this study, we restricted our sample to the foreign born whose citizenship response was not allocated - it was either as reported or determined from their reported place of birth. Approximately 2 percent of individuals in the unweighted 2006-2010 ACS were excluded due to allocated citizenship status.
} 
administrative records. For this portion of the analysis, we further restrict our sample to foreignborn respondents whose age at the time of the ACS was 25 years or older in order to evaluate socioeconomic characteristics such as employment status and educational attainment.

The explanatory variables in our analysis include: length of time in the United States, citizenship status, English language proficiency, educational attainment, household income, ${ }^{6}$ median income of the tract, employment, occupation, and percent of the Census tract that is foreign born. Demographic characteristics of individuals include age, sex, race, and Hispanic origin. We also control for marital status, household size, whether the individual lives in group quarters, and county population size. For the separate analysis of Hispanics we include the percent of the Census tract that is Hispanic, and for the analysis of non-Hispanic Asians we include the percent of the Census tract that is non-Hispanic Asian.

\section{Limitations}

A match to administrative records can only be determined for individuals for whom a PIK is assigned. The Census Bureau has examined the potential bias of studies restricted to the population with PIKs and found that PIK assignments vary by characteristics (Bond et al. 2014). While we account for this by including individuals who were not assigned PIKs in our analysis, we cannot determine whether those individuals are present in the administrative records files.

The process of assigning PIKs involves matching personally identifiable information in the ACS to a set of federal administrative records including the Social Security Administration's Numident file, including all Social Security Numbers (SSN) issued. Foreign born persons who have not obtained a SSN are less likely to get a PIK. To mitigate, the Census Bureau has tested use of Individual Taxpayer Identification Numbers (ITIN) observed in tax data. Individuals may obtain an ITIN to pay taxes when they cannot obtain a SSN. The ITIN matching was conducted for ACS data collected in 2010 only $^{7}$,

Additionally, the sample universe used in this study is restricted to those who responded to the ACS, and this population may be more likely to be in administrative records data relative to those who are harder to reach.

The data were obtained and compiled for an evaluation of administrative records relative to the 2010 Census. Thus, the reference period for the majority of these data is April 1, 2010. As the ACS data used in this analysis was collected from January 2006 through December 2010, the time frame of the files we are comparing do not match. This difference in reference period may be a reason that some individuals in the ACS are not present in administrative records data (i.e. migration or mortality).

\footnotetext{
${ }^{6}$ For individuals living in group quarters, personal income was used instead of household income.

${ }^{7}$ Additional research is underway to assess PIKs determined through Numident matching and ITIN matching. A key difference in the matching involves date of birth: this important field is available in the Numident but not in the tax data containing ITINs.
} 


\section{Results}

To what extent do administrative records provide data on the foreign born?

Table 1 presents the number and percent of individuals in the ACS who match to at least one administrative records file in our analysis by nativity and survey year. Of the 2.2 million foreignborn individuals in our sample universe, 1.75 million, or 79.5 percent, are assigned a PIK. For natives, we find a higher rate of PIK assignment (93.9 percent). The last two columns of Table 1 show the percent of individuals that match to administrative records - first as a percent of those with PIKs and second as a percent of total persons. If we consider only cases with PIKs, the percent that match to administrative records is high for both the foreign born (97.6 percent) and natives (98.6 percent). This indicates that the administrative records files in our analysis provide high coverage for individuals in our universe that receive a PIK. ${ }^{8}$ However, due to the lower PIK assignment among foreign-born individuals, the number of cases that match as a percent of the total sample is lower for the foreign born (77.6 percent) compared to natives (92.6 percent).

PIK assignment rates by survey year (also shown in Table 1) indicate that the percent of foreignborn individuals assigned a PIK is significantly higher in 2010 than in previous years, as expected based on the addition of the ITIN file in the PVS process for that year. This is consistent with findings by Bond et al. (2014) who find higher PVS rates for non-citizens in the 2010 ACS compared to the 2009 ACS. For natives we see a small but still significant increase in the percent of individuals with PIKs. The percent of all individuals that match to administrative records (the last column of the table) is higher for 2010 for both the foreign born and natives relative to earlier years. This is expected as an increase in PIK rates in 2010 results in more cases in this year for whom a match to administrative records can be determined. Match rates as a percent of those with PIKs, on the other hand, decrease for the foreign born. This suggests that individuals assigned a PIK in 2010 due to the inclusion of the ITIN data in the reference file may have lower rates of matching to administrative records compared to the foreign born overall.

Figure 1 shows administrative records coverage at the state level. The percent of foreign-born individuals that both receive a PIK and match to administrative records ranges from 65.0 percent in Alabama to 88.6 percent in Maine. In dark orange, we show states for which at least 80 percent of foreign-born individuals in our sample are assigned PIKs and match to administrative records - most northeastern states are in this category. In the lightest green we show states where less than 70 percent of foreign-born individuals in our sample are assigned PIKs and match to administrative records - these states are mostly in the south. When we consider only individuals who have a PIK, match rates are high (over 95 percent) for all states.

In Table 2, we show the percent of individuals who match to federal data and those that match to third party data, as well as match rates for each individual administrative records file. In this table, we only include individuals with PIKs. A large percent of both foreign-born and native individuals in our sample - 95.9 percent and 96.8 percent respectively - match to at least one of the federal files in our analysis. Among federal files, the highest coverage comes from tax data. For the foreign born in our sample, 86.3 percent are present in IRS 1040 data and 79.7 percent in

\footnotetext{
${ }^{8}$ Weighted descriptive and regression analysis results are similar to the unweighted results presented in the paper, and are available upon request.
} 
IRS 1099 data. Coverage by tax data is similar for natives, approximately 86.7 percent match to IRS 1040 data and 75.9 percent to IRS 1099 data.

The federal file that provides the next highest coverage is the Medicare Enrollment Database18.2 percent of the foreign born and 20.5 percent of natives in our sample match to this file. ${ }^{9}$ Coverage by the remaining federal files is limited, under 6 percent for both foreign born and natives.

Third party data coverage is substantial but lower than the coverage provided by federal files 81.9 percent of the foreign born and 76.1 percent of natives in our sample match to one or more third party files. The higher match rate for the foreign born relative to natives is unexpected but further investigation suggests it is a result of the age-specific coverage of third party data and differences in the age distribution of the foreign born and natives in our sample. As described earlier, third party data are based on sources such as credit bureau header data, utility records, and white pages. Thus, we expect third party data to cover the adult population more so than children. The foreign born in our sample have a lower percent of young individuals relative to natives - for example, 12.1 percent of the foreign born in our sample are under the age of 25 while 32.5 percent of natives in our sample are under $25 .{ }^{10}$ When we restrict our analysis to those ages 25 and older, third party data coverage is higher for natives (98.3 percent) than for the foreign born (88.4 percent).

What characteristics are associated with foreign-born coverage in administrative records?

For the remaining analysis, we focus on coverage for the combined administrative records source files and restrict our universe to those who are ages 25 and older in order to include socioeconomic variables (such as educational attainment and labor force participation) that are not available for young children. Overall PIK assignment rates and administrative records coverage increase slightly when we restrict our sample to those ages 25 and higher. The percent of the foreign born who were assigned a PIK is 82.9 percent for those ages 25 and higher compared to 79.5 percent for those of all ages. Of those with PIKs, 98.2 percent for the foreign born ages 25 and higher match to administrative records compared to 97.6 percent of the foreign born of all ages. PIK assignment rates and administrative records coverage by survey year and source file for those ages 25 and higher are shown in Appendix Tables 1 and 2.

\section{Descriptives}

We now turn to the second research question and assess the characteristics associated with foreign-born coverage by the compilation of administrative records. In Figure 2, ${ }^{11}$, we present for various characteristics the percent of individuals who a) receive a PIK and match to administrative records, b) receive a PIK and do not match to administrative records, and c) do not receive a PIK.

\footnotetext{
${ }^{9}$ If we restrict our universe to those whose age in the ACS was 65 or older, the percent who match to the Medicare Enrollment Database is 89.5 for the foreign born and 93.9 for natives.

${ }^{10}$ Note, while the foreign born have higher fertility rates than natives (Livingston and Cohn 2012), children of the foreign born who are born in the United States are natives.

${ }^{11}$ Numbers associated with Figure 2 are shown in Appendix Table 3.
} 
The solid blue section of the bars shows the percent who both receive a PIK and match to administrative records. For all characteristics this is the largest group - indicating that administrative records coverage is substantial for the foreign born across characteristics. However, there is variation - non-citizens and those who arrived to the United States within the last ten years are less likely to match to administrative records relative to naturalized citizens and those who entered the country more than ten years ago.

In red with dots, we show individuals who are assigned a PIK but do not match to our administrative records. This category makes up a very small proportion across characteristics. There is some variation - for example among recent immigrants we find a higher percentage who have a PIK but do not match to administrative records compared to those who have lived in the United States for more than 20 years (3.7 percent versus 0.6 percent). For both groups the proportion who have PIKs but do not match to one or more administrative records file in our analysis is low.

Finally, in green, we show the percent of individuals who are not assigned a PIK.

Compared to the foreign born who receive a PIK (the blue and red bars), those without PIKs are more likely to be younger, have lived in the United States for less than ten years, and be noncitizens.

\section{Regression results}

Results from our first multinomial regression using the 25 and older sample including all race and Hispanic origin groups are shown in Table 3. These results model the odds of a) not having a PIK and b) having a PIK that does not match to administrative records relative to our reference category of having a PIK that does match to one or more administrative records file.

As predicted, years in the United States, citizenship status, and English language proficiency are predictors of being assigned a PIK and being in administrative records. The odds of being in administrative records are lower for non-citizens and recent immigrants who have been in the United States for fewer than ten years compared to naturalized citizens and long-term immigrants (who have lived in the United States for 20 years or more). Individuals with lower English proficiency have lower odds of being in administrative records than English monolinguals. We find generally similar patterns for these characteristics in predicting the odds of being assigned a PIK, though there are differences in the level of significance.

Higher socioeconomic status is also associated with increased odds of being in administrative data. Individuals with no high school diploma are less likely to be in administrative records compared to those who have a high school diploma, have attended some college, or have a bachelor's degree or higher. Additionally, the odds of being in administrative records increase with income and with the median income of the tract. These characteristics have similar impacts on the odds of being assigned a PIK.

Labor force participation and employment are generally tied to higher odds of being in administrative records, though this varies by occupation groups. The results suggest differences among those employed in blue-collar versus white-collar jobs - with those in blue-collar jobs 
(e.g., natural resources, construction, and maintenance occupations) often being less likely to be assigned a PIK or to be in administrative records relative to those not in the labor force; in contrast, those in white-collar jobs (e.g., management, business, arts, science, sales, and office occupations) are more likely to be in administrative records than those not in the labor force. This is not always the case, for example individuals in production, transportation, and materialmoving occupations have higher odds of being in administrative records than those not in the labor force.

The amount of time worked in the last year also plays a role. Individuals who worked full time are more likely to be in administrative data compared to those who worked part time and those who did not work in the past year. Part-time workers are more likely to be in the category of having a PIK that did not match to administrative records compared to those who worked fulltime.

Foreign born living in tracts with high concentrations of foreign-born persons have lower odds of being assigned a PIK and of matching to administrative records relative to those living in areas with a lower percent foreign born.

Compared to non-Hispanic Whites, the non-Hispanic Black and Asian foreign born have higher odds of being assigned a PIK and matching to administrative records. Hispanics, on the other hand, have lower odds of being assigned a PIK and matching to administrative records. In a reduced model with race as the only independent variable, non-Hispanic single-race Whites have higher odds of being in administrative records compared to all other race and origin groups.

As discussed earlier, PIK and match rates vary by survey year, with rates for 2010 being notably different from earlier years due to differences in data and methodology used in the PIK assignment process. Regression analyses for each survey year, shown in Appendix Table 4, indicate that for some variables we see differences that may be partially explained by the different methodology in 2010. For example, the odds ratio for non-citizens for those who have PIKs but do not match to administrative records is higher in 2010 than in any of the previous years. This may be a result of the non-citizens added to the sample through the inclusion of ITIN data as a reference file having lower rates of matching than the overall foreign born. For most characteristics, however, odds ratios are relatively consistent across survey year.

In Tables 4 and 5, we present results of models run for the Hispanic (Table 6) and the nonHispanic single-race Asian (Table 7) foreign born. ${ }^{12}$ In general, we find that many of the same factors influence administrative records coverage for both groups. As with the overall foreign born, naturalization and years in the United States are associated with administrative records coverage for both Hispanic and Asian foreign born - non-citizens and more recent entrants are less likely to be in administrative records than their counterparts. There are some differences in results for the Hispanic and Asian foreign born.

For Hispanics, as we find for the overall foreign born, those living in tracts with a higher concentration of foreign-born individuals are less likely to be in administrative records. In

\footnotetext{
${ }^{12}$ For the remainder of this paper we will refer to the non-Hispanic single-race Asian sample as Asian for shorthand.
} 
contrast, a higher percentage of Hispanics (regardless of nativity) living in the tract is associated with greater odds of being in administrative records. We find similar results for the odds of being assigned a PIK - Hispanic foreign born living in high foreign-born areas have lower odds of receiving a PIK while those living in areas with a high percentage of Hispanics have higher odds of receiving PIKs.

For Asians, we see a different pattern. Both the percent of the tract that is foreign born and the percent of the tract that is Asian, are for the most part not significantly associated with administrative records coverage for foreign-born Asians. One exception is that living in tracts where 15 to 30 percent of the population was Asian is associated with lower odds of being in administrative records relative to tracts with a low Asian population. While the foreign-born and Asian makeup of the tract is for the most part not significantly associated with matching to administrative records for those with PIKs, these indicators are significant in terms of PIK assignment rates. For the Asian foreign born, living in tracts with a higher percentage foreign born and tracts with a higher percentage of Asians is associated with lower odds of being assigned a PIK.

\section{Discussion}

Our analysis on the magnitude of coverage and descriptive analysis on the characteristics of administrative records coverage indicate that for foreign-born individuals with PIKs, coverage by administrative records is high. However, the assignment of PIKs varies across different characteristics of the foreign born. For both PIK assignment and matches to administrative records, our findings confirm the hypothesis that indicators of assimilation are important factors in administrative records coverage of foreign-born individuals. Living in the country for a longer period of time, being a naturalized citizen, proficiency in English, and higher socioeconomic status are all tied to greater odds of being assigned a PIK and being in the administrative data used in this study. This suggests that the process of integration into society involves participation in programs and services that are included in our data.

Citizenship status has a large association with being in administrative records - naturalized citizens are significantly more likely to be found in administrative records relative to non U.S. citizens. This is not unexpected - gaining citizenship already signals their ability to navigate through government processes, which allow for even greater economic and social integration. Additionally, citizenship status is an eligibility factor for some of the government benefit programs included in this analysis. Length of time in the United States is also an eligibility factor and moreover, long-term immigrants have simply had more time to become involved in commercial activities and government programs relative to recent immigrants.

Our finding that English language proficiency and socioeconomic status are associated with administrative records coverage may also be related to individuals’ ability to navigate government processes, many of which are conducted primarily in English, as well as increased involvement in commercial activities among those with financial resources. Additionally, higher income and participation in the labor force may result in persons being required to file taxes and thus being in IRS data. Employment and occupation were also related to administrative records coverage, suggesting administrative records have lower coverage of those in informal positions. 
In our first model, we find that controlling for other factors, Asians are more likely to be in administrative records compared to our reference group (non-Hispanic Whites) while Hispanics are less likely to be in administrative records. Differences in human capital held by Hispanic and Asian immigrants when arriving in the country and the experiences they face may result in various paths of integration and these differences in the likelihood of being in administrative records. Yet, as we find in our separate models for Asians and Hispanics, many of the characteristics we considered have similar impacts on PIK assignment and administrative records coverage for both groups. Our finding that non-Hispanic single-race Black immigrants are more likely to match to administrative records relative to non-Hispanic single-race White immigrants is somewhat surprising in the context of segmented assimilation theory which asserts that racial and ethnic discrimination can act as barriers in the assimilation process (Portes et al. 2005).

For both Asians and Hispanics, as well as the total foreign born, living in neighborhoods with a higher percent foreign born is associated with lower odds of being assigned a PIK and in the case of Hispanics, lower odds of matching to administrative records. We find differing impacts for Hispanics and for Asians regarding the presence of co-ethnics in the neighborhood. For the Hispanic foreign born, living in areas with a higher percentage of Hispanic individuals (regardless of nativity) is associated with greater odds of being assigned a PIK and matching to administrative records. For the Asian foreign born, on the other hand, living in areas with a higher percent of non-Hispanic Asians is generally associated with lower odds of being assigned a PIK.

For the Hispanic foreign born, the opposing results for the density of foreign born versus density of Hispanics in the neighborhood may suggest differences between communities with many immigrants versus areas with a high concentration of second and later generation Hispanics. In communities with a high concentration of foreign-born persons, particularly where many of the residents are recent arrivals, there may be less knowledge of how to initiate and negotiate interactions with mainstream institutions or with government agencies. In contrast, neighborhoods with a high concentration of both foreign-born and native-born Hispanics, residents may have more knowledge about accessing resources and be able to share that information.

The differing results for the Hispanic and Asian foreign born may suggest differences in how immigrants from different backgrounds interact with other immigrants and individuals of their race or origin. However, previous research on both Hispanics and Asians has found that living in ethnic enclaves can have similar impacts - both positive and negative - on socioeconomic status. Much of this research analyzes more detailed groups, thus one possible explanation for our findings is methodological. Our measure of "co-ethnics" in this analysis is quite broad. The Hispanic and Asian populations are diverse and our results may differ if we further refined our groupings into more detailed ethnic or country of origin groups. Overall, we find that many of the same characteristics associated with being assigned a PIK are also associated with matching to administrative records. 


\section{Conclusion}

As the Census Bureau moves forward in evaluations of administrative records for census and survey operations, the wider implications of this work must be kept in mind. Researchers should acknowledge variation in PIK assignment and administrative records coverage when using these data. Additionally, our findings on the characteristics associated with lower PIK assignment and administrative records coverage should inform the Census Bureau's efforts to improve PIK assignment and administrative records coverage.

Because we find gaps in PIK assignment rates and high administrative records coverage for individuals who are assigned a PIK, efforts should be made towards increased PIK assignment, particularly for populations with lower PIK rates such as Hispanics and recent immigrants. As shown in our analysis of PIK and match rates by survey year, the addition of ITIN information as a reference file increases the percent of individuals who are assigned a PIK and also increases the percent of individuals matching to administrative records data. We therefore recommend that information from the ITIN files should be used in the PVS process for all census and administrative records data and support continued research into improvements in the PIK assignment process.

While administrative records coverage is high among those with PIKs, acquisition of new data sources may also be useful in increasing coverage rates. The Census Bureau is currently evaluating and acquiring additional data sources to determine if they can enhance coverage of particular populations. In this process, attention should be paid to the coverage of the foreign born and in particular those with characteristics we find to be associated with lower coverage such as recent immigrants and non-citizens. The Census Bureau should investigate whether data from the Department of Homeland Security could help improve the coverage of the foreign born. In addition, the Census Bureau is pursuing data from the Supplementary Nutrition Assistance Program and Women, Infants, and Children Program. As these data sources are evaluated, researchers should consider whether these sources improve the coverage of the foreign-born population. 


\section{References}

Batalova, Jeanne. 2009. “Immigrant Women in the United States,” Washington, DC: Migration Policy Institute.

Bond Brittany, J. David Brown, Adela Luque, and Amy O’Hara. 2014. “The Nature of Bias When Studying Only Linkable Person Records: Evidence from the American Community Survey," Center for Administrative Records Research and Applications Working Paper Series, Paper No. 2014-08. Washington, DC: U.S. Census Bureau.

Borjas, George J. and Marta Tienda. 1993. “The Employment and Wages of Legalized Immigrants,” International Migration Review. Volume 27, No. 4: 712-747.

Broder, Tanya and Jonathan Blazer. 2011. “Overview of Immigrant Eligibility for Federal Programs,” National Immigration Law Center.

Brown, Susan K. and Frank D. Bean. 2006. “Assimilation Models, Old and New: Explaining a Long Term Process,” Washington, DC: Migration Policy Institute.

Capps, Randy and Karina Fortuny. 2006. “Immigration and Child and Family Policy”. Prepared for The Urban Institute and Child Trends Roundtable on Children in Low-Income Families: Paper 3.

Capps, Randy, Michael Fix, Jason Ost, Jane Reardon-Anderson and Jeffrey S. Passel. 2004. "The Health and Well-Being of Young Children of Immigrants,” Washington, DC: The Urban Institute.

Duleep, Harriet O. and Daniel J. Dowhan. 2008. “Incorporating Immigrant Flows into Microsimulation Models,” Social Security Bulletin, Vol. 68 No. 1.

Fix, Michael and Jeffrey S. Passel. 2002. “The Scope and Impact of Welfare Reform’s Immigrant Provisions,” Washington, DC: The Urban Institute.

Fortuny, Karina and Ajay Chaudry. 2011. "A Comprehensive Review of Immigrant Access to Health and Human Services,” U.S. Department of Health and Human Services.

Friedberg, Rachel M. and David A. Jaeger. 2009. "The Economic Diversity of Immigration Across the United States,” IZA Discussion Paper No. 4555.

Furtado, Delia, and Nikolaos Theodoropoulos. 2012. "Immigrant Networks and the Take-up of Disability Programs: Evidence from US Census Data,” Center for Retirement Research at Boston College Working Paper 2012-23.

Gordon, Milton M. 1964. “Assimilation in American Life: The Role of Race, Religion, and National Origins,” New York: Oxford University Press. 
Grieco, Elizabeth M., Yesenia D. Acosta, G. Patricia de la Cruz, Christine Gambino, Thomas Gryn, Luke J. Larsen. 2012. "The Foreign-born Population in the United States: 2010,” American Community Survey Reports, ACS-19. Washington, DC: U.S. Census Bureau.

Hagan, Jacqueline Maria. 1998. "Social networks, gender and immigrant incorporation: resources and constraints,” American Sociological Review, 63: 55-67.

Haller, William, Alejandro Portes, and Scott M. Lynch. 2011. Dreams Fulfilled, Dreams Shattered: Determinants of Segmented Assimilation in the Second Generation. Social Forces 89(3): 733-762.

Hernandez, Donald J. 2004. "Demographic Change and the Life Circumstances of Immigrant Families,” Future of Children: Children of Immigrant Families. Volume 4 Number 2.

Hill, Laura E. and Hans P. Johnson. 2011. “Unauthorized Immigrants in California,” Public Policy Institute of California.

Hoefer, Michael, Nancy Rytina, and Bryan Baker. 2012. "Estimates of the Unauthorized Immigrant Population Residing in the United States: January 2011,” Office of Immigration Statistics, Policy Directorate, U.S. Department of Homeland Security,

Jasso, Guillermina and Mark R. Rosenzweig. 1982. "Estimating the Emigration Rates of Legal Migrants Using Administrative and Survey Data: The 1971 Cohort of Immigrants to the United States,” Demography. Volume 19, Issue 3: 279-290.

Kandel, William A. 2011. "The U.S. Foreign-Born Population: Trends and Selected Characteristics,” Congressional Research Service.

Kim, Jeongsoo, Shelley K. Irving, and Tracy A. Loveless. 2012. "Dynamics of Economic WellBeing: Participation in Government Programs, 2004 to 2007 and 2009: Who Gets Assistance?” Current Population Reports, P70-131. Washington, DC: U.S. Census Bureau.

Kochar, Rakesh, Ana Gonzalez-Barrera, and Daniel Dockterman. 2009. "Through Boom and Bust: Minorities, Immigrants, and Homeownership,” Washington, DC: Pew Research Center.

Lee, Jennifer and Min Zhou. 2013. “Frames of Achievement and Opportunity Horizons.” In Card, David and Steven Raphael (Eds.), Immigration, Poverty, and Socioeconomic Inequality. NY: Russell Sage Foundation. Pp. 206-231.

Lee, Jennifer and Min Zhou. 2014. The Success Frame and Achievement Paradox: The Costs and Consequences for Asian Americans. Race and Social Problems 6(1): 38-55. 
Livingston, Gretchen and D’Vera Cohn. 2012. U.S. Birth Rate Falls to a Record Low; Decline is Greatest Among Immigrants. Washington, DC: Pew Research Center.

Luque, Adela and Renuka Bhaskar. 2013. “2010 American Community Survey Match Study,” Center for Administrative Records Research and Applications Working Paper Series, Paper No. 2014-03. U.S. Census Bureau.

Massey, Douglas S. and Chiara Capoferro. 2004. "Measuring Undocumented Migration,” International Migration Review Volume 38 Number 3: 1075-1102.

Menjívar, Cecilia. 2008. Educational Hopes, Documented Dreams: Guatemalan and Salvadoran Immigrants' Legality and Educational Prospects. The ANNALS of the American Academy of Political and Social Science 620 (1): 177-193.

Moohn, Betty. 2012. “2010 Census Integrated Communications Program Regional Partnership Assessment Report,” 2010 Census Program for Evaluations and Experiments, 2010 Planning Memoranda Series No. 217. Washington, DC: U.S. Census Bureau.

Mosisa, Abraham. 2002. “The Role of Foreign-born Workers in the U.S. Economy,” Monthly Labor Review, May 2002: 3-14.

Parks, Virginia. 2004. “Access to work: the effects of spatial and social accessibility on unemployment for native-born Black and immigrant women in Los Angeles,” Economic Geography, 80(2): 141-172.

Portes, Alejandro and Min Zhou. 1993. "The New Second Generation: Segmented Assimilation and Its Variants,” The Annals of the American Academy of Political and Social Science 530: 74-96.

Portes, Alejandro, Patricia Fernández-Kelly, and William Haller. 2005. “Segmented Assimilation on the Ground: The New Second Generation in Early Adulthood,” Ethnic and Racial Studies 28: 1000-1040.

Portes, Alejandro and Rubén G. Rumbaut. 2006. Immigrant America: a Portrait. University of California Press.

Quandt, Sara A., Thomas A. Argury, Julie Early, Janet Tapia, Jessie D. Davis. 2004. “Household Food Security among Migrant and Seasonal Latino Farmworkers in North Carolina," Public Health Reports, Volume 119, 568-576.

Rastogi, Sonya and Amy O’Hara. 2012. “Census Match Study,” 2010 Census Program for Evaluations and Experiments, 2010 Planning Memoranda Series No. 247. Washington, DC: U.S. Census Bureau. 
Sanders Jimy M. and Victor Nee. 1987. "Limits of Ethnic Solidarity in the Enclave Economy," American Sociological Review. Vol 53. No. 6: 745-773.

Schwabash, Jonathan A. 2011. "Identifying Rates of Emigration in the United States Using Administrative Earnings Records," International Journal of Population Research. Volume 2011, Article ID 546201.

Shierholz, Heidi. 2010. "The Effects of Citizenship on Family Income and Poverty,” Washington, DC: Economic Policy Institute.

Toussaint-Comeau, Maude. 2012. "Ethnic Social Networks and Self-Employment of Immigrant Men in the US,” Eastern Economic Journal, 38: 74-98.

Trevelyan, Edward, Yesenia D. Acosta, and G. Patricia de la Cruz. 2013. "Homeownership among the Foreign-Born Population: 2011”. American Community Survey Briefs, ACSBR/11-15. Washington, DC: U.S. Census Bureau.

U.S. Census Bureau. 2014. "Design and Methodology: American Community Survey.” Washington, DC: U.S. Census Bureau.

Villarejo, Don. 2003. "The Health of U.S. Hired Farm Workers," Annual Review of Public Health v. 24: 175-193.

Wagner, Deborah and Mary Layne. 2014. "The Person Identification Validation System (PVS): Applying the Center for Administrative Records Research \& Applications’ (CARRA) Record Linkage Software,” Center for Administrative Records Research and Applications Working Paper, Paper No. 2014-01. Washington, DC: U.S. Census Bureau.

Waldinger, Roger and Cynthia Feliciano. 2004. "Will the second generation experience ‘downward assimilation'? Segmented assimilation reassessed,” Ethnic and Racial Studies, 27 (3): 376-402.

Waters, Mary C. and Tomás R. Jiménez. 2005. "Assessing Immigrant Assimilation: New Empirical and Theoretical Challenges,” Annual Review of Sociology, Vol. 31: 105-125.

Wilson, Kenneth and Alejandro Portes. 1980. "Immigrant enclaves: an analysis of the labor market experiences of Cubans in Miami," American Journal of Sociology, 86(2): 295319.

Xie, Yu and Margaret Gough. 2011. "Ethnic enclaves and the earnings of immigrants," Demography, 48: 1293-1315.

Zhou, Min. 2009. "How Neighborhoods Matter for Immigrant Children: The Formation of Educational Resources in Chinatown, Koreatown, and Pico Union, Los Angeles,” Journal of Ethnic and Migration Studies 35(7): 1153-1179. 


\section{Acknowledgements}

We would like to thank Amy O’Hara, Adela Luque, Mark Leach, and B. Dale Garrett for their valuable comments and suggestions. 
Table 1. PIK Assignment and Matching to Administrative Records by Nativity and ACS Survey Year Universe: Persons with non-allocated citizenship

\begin{tabular}{|l|r|r|r|r|r|r|}
\hline Nativity and Survey & \multicolumn{1}{l}{$\begin{array}{l}\text { Total number } \\
\text { Year sample }\end{array}$} & \multicolumn{2}{|c|}{ Assigned a PIK } & \multicolumn{3}{|c|}{ Match to AR } \\
\cline { 3 - 7 } & & & & & $\begin{array}{c}\text { Percent of } \\
\text { those with } \\
\text { PIKs }\end{array}$ & $\begin{array}{c}\text { Percent of } \\
\text { total } \\
\text { sample }\end{array}$ \\
\hline Foreign Born & $2,201,371$ & $1,750,865$ & 79.5 & $1,708,869$ & 97.6 & 77.6 \\
2006 & 441,865 & 342,745 & 77.6 & 335,738 & 98.0 & 76.0 \\
2007 & 438,526 & 339,929 & 77.5 & 334,123 & 98.3 & 76.2 \\
2008 & 430,914 & 335,243 & 77.8 & 330,458 & 98.6 & 76.7 \\
2009 & 441,182 & 337,512 & 76.5 & 333,464 & 98.8 & 75.6 \\
2010 & 448,884 & 395,436 & 88.1 & 375,086 & 94.9 & 83.6 \\
& & & & & & \\
Native Born & $19,959,597$ & $18,746,422$ & 93.9 & $18,480,141$ & 98.6 & 92.6 \\
2006 & $4,117,584$ & $3,874,602$ & 94.1 & $3,821,352$ & 98.6 & 92.8 \\
2007 & $4,026,913$ & $3,774,878$ & 93.7 & $3,725,786$ & 98.7 & 92.5 \\
2008 & $3,963,710$ & $3,710,368$ & 93.6 & $3,663,678$ & 98.7 & 92.4 \\
2009 & $3,951,309$ & $3,669,411$ & 92.9 & $3,623,958$ & 98.8 & 91.7 \\
2010 & $3,900,081$ & $3,717,163$ & 95.3 & $3,645,367$ & 98.1 & 93.5 \\
\hline
\end{tabular}

Source: 2006-2010 5-year American Community Survey data and 2010 Administrative Records data 
Table 2. Percent of Persons Who Match to Administrative Records by Source File and Nativity Universe: Persons with PIKs and non-allocated citizenship

\begin{tabular}{|l|r|r|}
\hline Administrative Records Source File & Foreign Born & \multicolumn{1}{|c|}{ Natives } \\
\hline Total in Sample & $1,750,865$ & $18,746,422$ \\
Percent in... & & \\
Any administrative record (federal and third party data) & 97.6 & 98.6 \\
Federal data & 95.9 & 96.8 \\
IRS 1040 & 86.3 & 86.7 \\
IRS 1099 & 79.7 & 75.9 \\
Medicare Enrollment Database & 18.2 & 20.5 \\
HUDCHUMS & 5.5 & 4.1 \\
SSR & 3.5 & 2.2 \\
SSS & 2.8 & 4.7 \\
HUDPIC & 1.8 & 1.8 \\
HUDTRACS & 1.0 & 0.7 \\
Indian Health Service & 0.4 & 2.0 \\
Temporary Assistance for Needy Families & 0.2 & 0.6 \\
Third party data & 81.9 & 76.1 \\
File 1 & 52.6 & 54.1 \\
File 2 & 69.1 & 67.7 \\
File 3 & 55.0 & 56.1 \\
File 4 & 25.0 & 24.6 \\
File 5 & 69.5 & 64.9 \\
File 6 & 10.8 & 10.0 \\
File 7 & 41.3 & 45.2 \\
File 8 & 66.5 & 62.6 \\
\hline
\end{tabular}

Source: 2006-2010 5-year American Community Survey data and 2010 Administrative Records data 
Table 3. Odds of Being in Administrative Records

Universe: Foreign-born ages 25 and older with non-allocated citizenship

\begin{tabular}{|c|c|c|c|c|}
\hline \multirow{3}{*}{$\begin{array}{l}\text { Variable [reference category] } \\
\text { Length of Residence in the U.S. [20+ years] }\end{array}$} & \multicolumn{2}{|c|}{ No PIK } & \multicolumn{2}{|c|}{$\begin{array}{c}\text { With a PIK, no } \\
\text { match to AR }\end{array}$} \\
\hline & \multicolumn{4}{|c|}{$\begin{array}{c}\text { Reference category: } \\
\text { With a PIK, match to AR }\end{array}$} \\
\hline & & & & \\
\hline 10 to 19 years & 1.65 & $* * *$ & 1.94 & $* * *$ \\
\hline Less than 10 years & 2.85 & $* * *$ & 4.28 & $* * *$ \\
\hline \multicolumn{5}{|l|}{ English Language Ability [Speaks only English at home] } \\
\hline Speaks English Very Well & 0.74 & $* * *$ & 1.01 & \\
\hline Speaks English Well & 0.94 & $* * *$ & 1.24 & $* * *$ \\
\hline Speaks English Not Well & 1.33 & $* * *$ & 1.40 & $* * *$ \\
\hline Speaks English Not at All & 1.70 & $* * *$ & 1.51 & $* * *$ \\
\hline \multicolumn{5}{|l|}{ Citizenship [Naturalized U.S. Citizen] } \\
\hline Not a U.S. Citizen & 1.89 & $* * *$ & 5.51 & $* * *$ \\
\hline \multicolumn{5}{|l|}{ Educational Attainment [No High School Degree] } \\
\hline High School Degree & 1.05 & $* * *$ & 0.95 & $* *$ \\
\hline Some College & 0.78 & $* * *$ & 0.77 & $* * *$ \\
\hline Bachelors Degree or Higher & 0.81 & $* * *$ & 0.96 & \\
\hline \multicolumn{5}{|l|}{ Type of Employment [Full time worker] } \\
\hline Part time worker & 0.88 & $* * *$ & 1.37 & $* * *$ \\
\hline Did not work last year & 1.13 & $* * *$ & 2.01 & $* * *$ \\
\hline \multicolumn{5}{|l|}{ Occupation [Not in Labor Force] } \\
\hline Management/Business/Science/ Arts & 0.52 & $* * *$ & 0.58 & $* * *$ \\
\hline Service & 0.99 & & 0.82 & $* * *$ \\
\hline Sales/Office & 0.71 & $* * *$ & 0.56 & $* * *$ \\
\hline Natural resources/ Construction/Maintenance & 1.29 & $* * *$ & 1.10 & ** \\
\hline Production/transportation /material moving & 0.74 & $* * *$ & 0.57 & $* * *$ \\
\hline Military Specific & 0.56 & $* * *$ & 1.40 & \\
\hline Unemployed & 0.79 & $* * *$ & 1.00 & \\
\hline Log of household/personal income ${ }^{a}$ & 0.93 & $* * *$ & 0.93 & $* * *$ \\
\hline Median Income of Tract & 0.96 & $* * *$ & 0.95 & $* * *$ \\
\hline Sample Size & 316 , & & 28,3 & \\
\hline
\end{tabular}

Source: 2006-2010 5-year American Community Survey data and 2010 Administrative Records Data

${ }^{\mathrm{a}}$ The log of household income is used for individuals in housing units while the log of personal income is used for those living in group quarters.

${ }^{*} \mathrm{p}<=.05,{ }^{* *} \mathrm{p}<=.01,{ }^{* * *} \mathrm{p}<=.001$

(continued) 
Table 3, continued

Universe: Foreign-born ages 25 and older with non-allocated citizenship

\begin{tabular}{|c|c|c|c|c|}
\hline \multirow{3}{*}{$\begin{array}{l}\text { Variable [reference category] } \\
\text { Percent of tract that is foreign born [Less than 15\%] }\end{array}$} & \multicolumn{2}{|c|}{ No PIK } & \multicolumn{2}{|c|}{$\begin{array}{l}\text { With a PIK, no } \\
\text { match to AR }\end{array}$} \\
\hline & \multicolumn{4}{|c|}{$\begin{array}{c}\text { Reference category: } \\
\text { With a PIK, match to AR }\end{array}$} \\
\hline & & & & \\
\hline 15 to $<30$ percent & 1.08 & $* * *$ & 1.08 & $* * *$ \\
\hline 30 to $<45$ percent & 1.16 & $* * *$ & 1.08 & $* * *$ \\
\hline 45 percent or more & 1.28 & $* * *$ & 1.07 & $* * *$ \\
\hline \multicolumn{5}{|l|}{ County Population [500,000 or more] } \\
\hline Less than 100,000 & 1.32 & $* * *$ & 1.12 & $* * *$ \\
\hline 100,000 to 499,999 & 1.04 & $* * *$ & 1.02 & \\
\hline \multicolumn{5}{|l|}{ Race [Non-Hispanic White] } \\
\hline Non-Hispanic Black & 0.98 & $*$ & 0.80 & $* * *$ \\
\hline Non-Hispanic Asian & 0.88 & $* * *$ & 0.84 & $* * *$ \\
\hline Non-Hispanic Other & 1.07 & & 1.03 & \\
\hline Hispanic & 1.75 & $* * *$ & 1.11 & $* * *$ \\
\hline \multicolumn{5}{|l|}{ Sex [Male] } \\
\hline Female & 0.89 & $* * *$ & 0.81 & $* * *$ \\
\hline \multicolumn{5}{|l|}{ Age Category [25 to 44$]$} \\
\hline 45 to 64 & 0.62 & $* * *$ & 0.79 & $* * *$ \\
\hline 65 and older & 0.46 & $* * *$ & 0.91 & $* * *$ \\
\hline \multicolumn{5}{|l|}{ Marital Status [Now Married] } \\
\hline Widowed, Separated, or Divorced & 1.19 & $* * *$ & 1.52 & $* * *$ \\
\hline Never Married & 1.74 & $* * *$ & 2.17 & $* * *$ \\
\hline \multicolumn{5}{|l|}{ Number of Persons in Household [Fewer than 6 people] } \\
\hline 6 or More People & 1.23 & $* * *$ & 1.40 & $* * *$ \\
\hline Group Quarter & 1.78 & $* * *$ & 3.54 & $* * *$ \\
\hline Sample Size & 316 , & & 28,3 & \\
\hline
\end{tabular}

Source: 2006-2010 5-year American Community Survey data and 2010 Administrative Records Data ${ }^{*} \mathrm{p}<=.05,{ }^{* *} \mathrm{p}<=.01, * * * \mathrm{p}<=.001$ 
Table 4. Odds of Being in Administrative Records: Hispanic Foreign Born

Universe: Hispanic foreign-born ages 25 and older with non-allocated citizenship

\begin{tabular}{|l|r|rr|}
\hline \multirow{2}{*}{ Variable [reference category] } & No PIK & $\begin{array}{c}\text { With a PIK, no } \\
\text { match to AR }\end{array}$ \\
\cline { 2 - 5 } & \multicolumn{3}{|c|}{ Reference category: } \\
With a PIK, match to AR
\end{tabular}

Source: 2006-2010 5-year American Community Survey data and 2010 Administrative Records Data

${ }^{a}$ The log of household income is used for individuals in housing units while the log of personal income is used for those living in group quarters.

${ }^{*} \mathrm{p}<=.05, * * \mathrm{p}<=.01, * * * \mathrm{p}<=.001$

(continued) 
Table 4, continued

Universe: Hispanic foreign-born ages 25 and older with non-allocated citizenship

\begin{tabular}{|c|c|c|c|c|}
\hline \multirow{3}{*}{$\begin{array}{l}\text { Variable [reference category] } \\
\text { Percent of tract that is foreign born [Less than 15\%] }\end{array}$} & \multicolumn{2}{|c|}{ No PIK } & \multicolumn{2}{|c|}{$\begin{array}{c}\text { With a PIK, no } \\
\text { match to AR }\end{array}$} \\
\hline & \multicolumn{4}{|c|}{$\begin{array}{c}\text { Reference category: } \\
\text { With a PIK, match to AR }\end{array}$} \\
\hline & & & & \\
\hline 15 to $<30$ percent & 1.05 & $* * *$ & 1.05 & \\
\hline 30 to $<45$ percent & 1.20 & $* * *$ & 1.16 & $* * *$ \\
\hline 45 percent or more & 1.30 & $* * *$ & 1.19 & $* * *$ \\
\hline \multicolumn{5}{|l|}{ Percent of tract that is Hispanic [Less than 15\%] } \\
\hline 15 to $<40$ percent & 1.00 & & 0.90 & $* * *$ \\
\hline 40 to $<75$ percent & 0.93 & $* * *$ & 0.83 & $* * *$ \\
\hline 75 percent or more & 0.78 & $* * *$ & 0.71 & $* * *$ \\
\hline \multicolumn{5}{|l|}{ County Population [500,000 or more] } \\
\hline Less than 100,000 & 1.30 & $* * *$ & 1.15 & $* * *$ \\
\hline 100,000 to 499,999 & 1.08 & $* * *$ & 1.03 & \\
\hline \multicolumn{5}{|l|}{ Sex [Male] } \\
\hline Female & 0.79 & $* * *$ & 0.75 & $* * *$ \\
\hline \multicolumn{5}{|l|}{ Age Category [25 to 44$]$} \\
\hline 45 to 64 & 0.51 & $* * *$ & 0.70 & $* * *$ \\
\hline 65 and older & 0.31 & $* * *$ & 0.74 & $* * *$ \\
\hline \multicolumn{5}{|l|}{ Marital Status [Now Married] } \\
\hline Widowed, Separated, or Divorced & 1.23 & $* * *$ & 1.41 & $* * *$ \\
\hline Never Married & 1.80 & $* * *$ & 2.11 & $* * *$ \\
\hline \multicolumn{5}{|l|}{ Number of Persons in Household [Fewer than 6 people] } \\
\hline 6 or More People & 1.25 & $* * *$ & 1.39 & $* * *$ \\
\hline Group Quarter & 1.65 & $* * *$ & 2.85 & $* * *$ \\
\hline Sample size & 210,2 & & 15,100 & \\
\hline
\end{tabular}

Source: 2006-2010 5-year American Community Survey data and 2010 Administrative Records Data ${ }^{*} \mathrm{p}<=.05,{ }^{* *} \mathrm{p}<=.01,{ }^{* * *} \mathrm{p}<=.001$ 
Table 5. Odds of Being in Administrative Records: Non-Hispanic Asian Foreign Born

Universe: Non-Hispanic Asian foreign-born ages 25 and older with non-allocated citizenship

\begin{tabular}{|c|c|c|c|c|}
\hline \multirow{3}{*}{$\begin{array}{l}\text { Variable [reference category] } \\
\text { Length of Residence in the U.S. [20+ years] }\end{array}$} & \multicolumn{2}{|c|}{ No PIK } & \multicolumn{2}{|c|}{$\begin{array}{l}\text { With a PIK, no } \\
\text { match to AR }\end{array}$} \\
\hline & \multicolumn{4}{|c|}{$\begin{array}{c}\text { Reference category: } \\
\text { With a PIK, match to AR }\end{array}$} \\
\hline & & & & \\
\hline 10 to 19 years & 1.08 & $* * *$ & 1.28 & $* * *$ \\
\hline Less than 10 years & 1.88 & $* * *$ & 4.98 & $* * *$ \\
\hline \multicolumn{5}{|l|}{ English Language Ability [Speaks only English at home] } \\
\hline Speaks English Very Well & 0.73 & $* * *$ & 0.81 & $* * *$ \\
\hline Speaks English Well & 0.83 & $* * *$ & 1.14 & $*$ \\
\hline Speaks English Not Well & 1.12 & $* * *$ & 1.29 & $* * *$ \\
\hline Speaks English Not at All & 1.75 & $* * *$ & 1.59 & $* * *$ \\
\hline \multicolumn{5}{|l|}{ Citizenship [Naturalized U.S. Citizen] } \\
\hline Not a U.S. Citizen & 1.58 & $* * *$ & 4.66 & $* * *$ \\
\hline \multicolumn{5}{|l|}{ Educational Attainment [No High School Degree] } \\
\hline High School Degree & 1.28 & $* * *$ & 0.99 & \\
\hline Some College & 1.01 & & 0.90 & $*$ \\
\hline Bachelors Degree or Higher & 1.16 & $* * *$ & 1.03 & \\
\hline \multicolumn{5}{|l|}{ Type of Employment [Full time worker] } \\
\hline Part time worker & 0.76 & $* * *$ & 1.46 & $* * *$ \\
\hline Did not work last year & 1.28 & $* * *$ & 2.13 & $* * *$ \\
\hline \multicolumn{5}{|l|}{ Occupation [Not in Labor Force] } \\
\hline Management/Business/Science/ Arts & 0.54 & $* * *$ & 0.52 & $* * *$ \\
\hline Service & 0.93 & & 0.51 & $* * *$ \\
\hline Sales/Office & 0.78 & $* * *$ & 0.45 & $* * *$ \\
\hline Natural resources/ Construction/Maintenance & 0.99 & & 0.44 & $* * *$ \\
\hline Production/transportation /material moving & 0.70 & $* * *$ & 0.30 & $* * *$ \\
\hline Military Specific & 0.71 & & 1.55 & \\
\hline Unemployed & 0.73 & $* * *$ & 0.88 & $*$ \\
\hline Log of household/personal income & 0.92 & $* * *$ & 0.93 & $* * *$ \\
\hline Median Income of Tract & 0.91 & $* * *$ & 0.89 & $* * *$ \\
\hline Sample size & & 035 & 6,0 & \\
\hline
\end{tabular}

Source: 2006-2010 5-year American Community Survey data and 2010 Administrative Records Data

${ }^{a}$ The log of household income is used for individuals in housing units while the log of personal income is used for those living in group quarters.

${ }^{*} \mathrm{p}<=.05, * * \mathrm{p}<=.01, * * * \mathrm{p}<=.001$

(continued) 
Table 5, continued

Universe: Non-Hispanic Asian foreign-born ages 25 and older with non-allocated citizenship

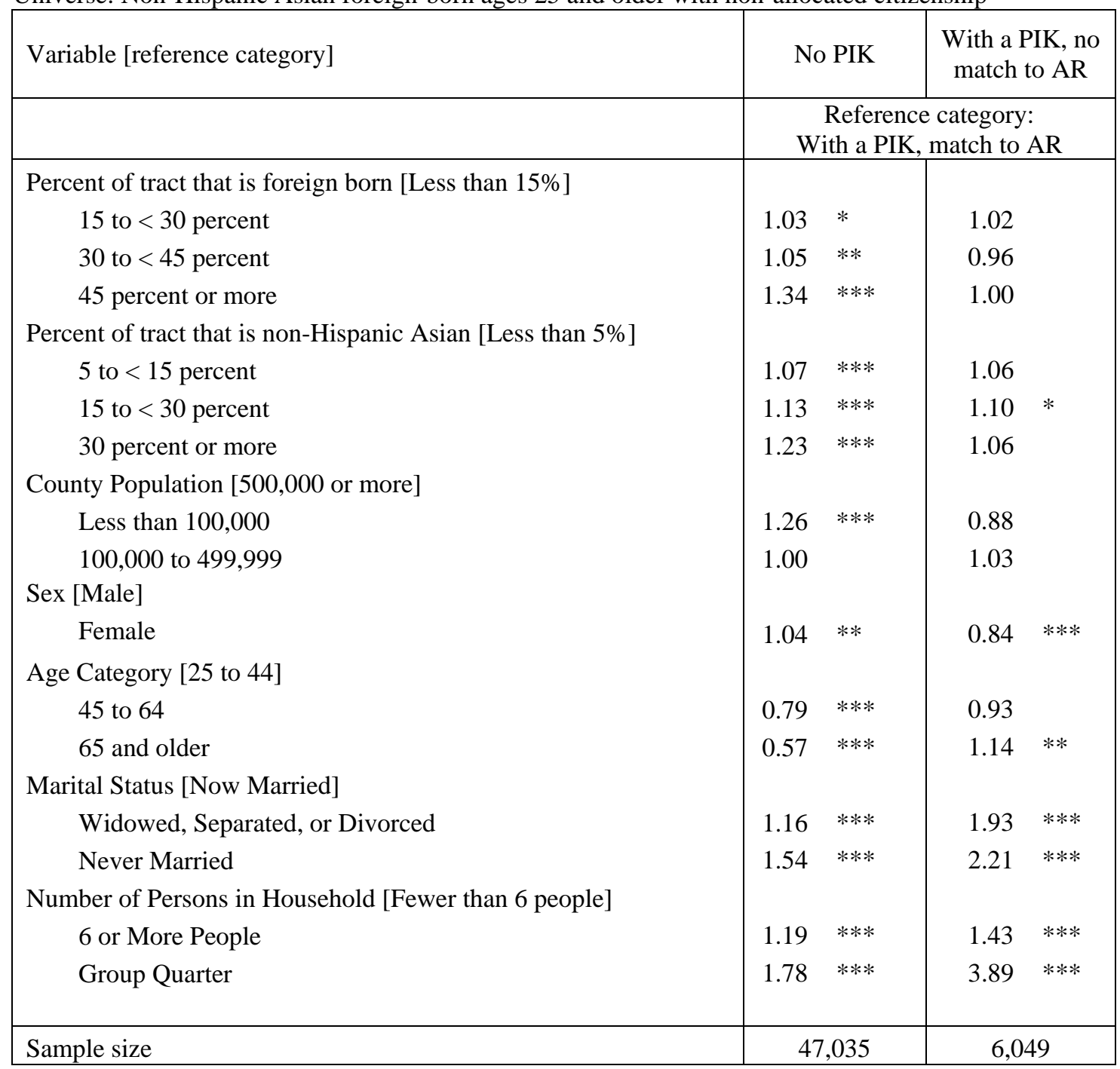

Source: 2006-2010 5-year American Community Survey data and 2010 Administrative Records Data ${ }^{*} \mathrm{p}<=.05,{ }^{* *} \mathrm{p}<=.01,{ }^{* * *} \mathrm{p}<=.001$ 


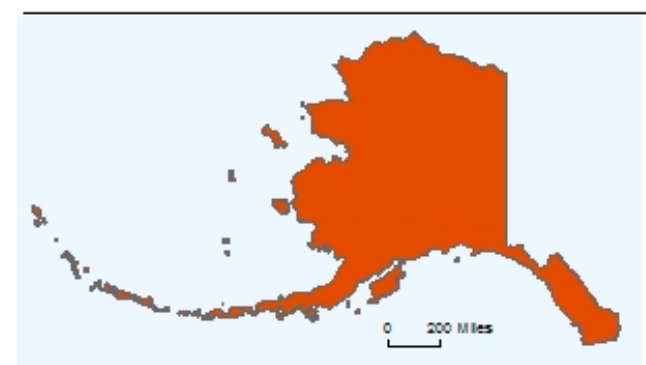

Figure 1.

Administrative Records Coverage for the Foreign Born by State

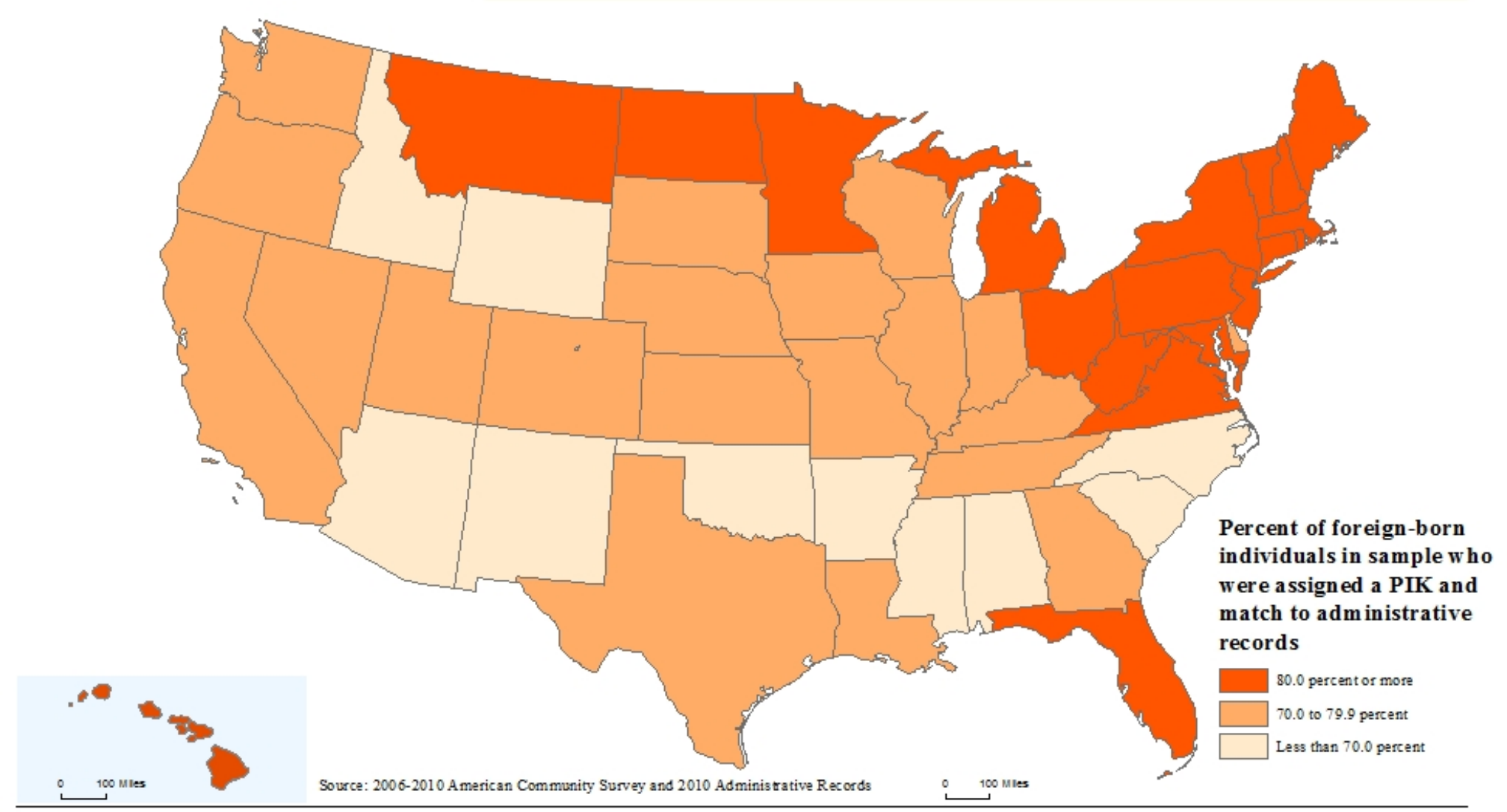


Figure 2. PIK Assignment and Administrative Records Coverage for the Foreign-born Population by Characteristic

Universe: Foreign-born ages 25 and older with non-allocated citizenship status

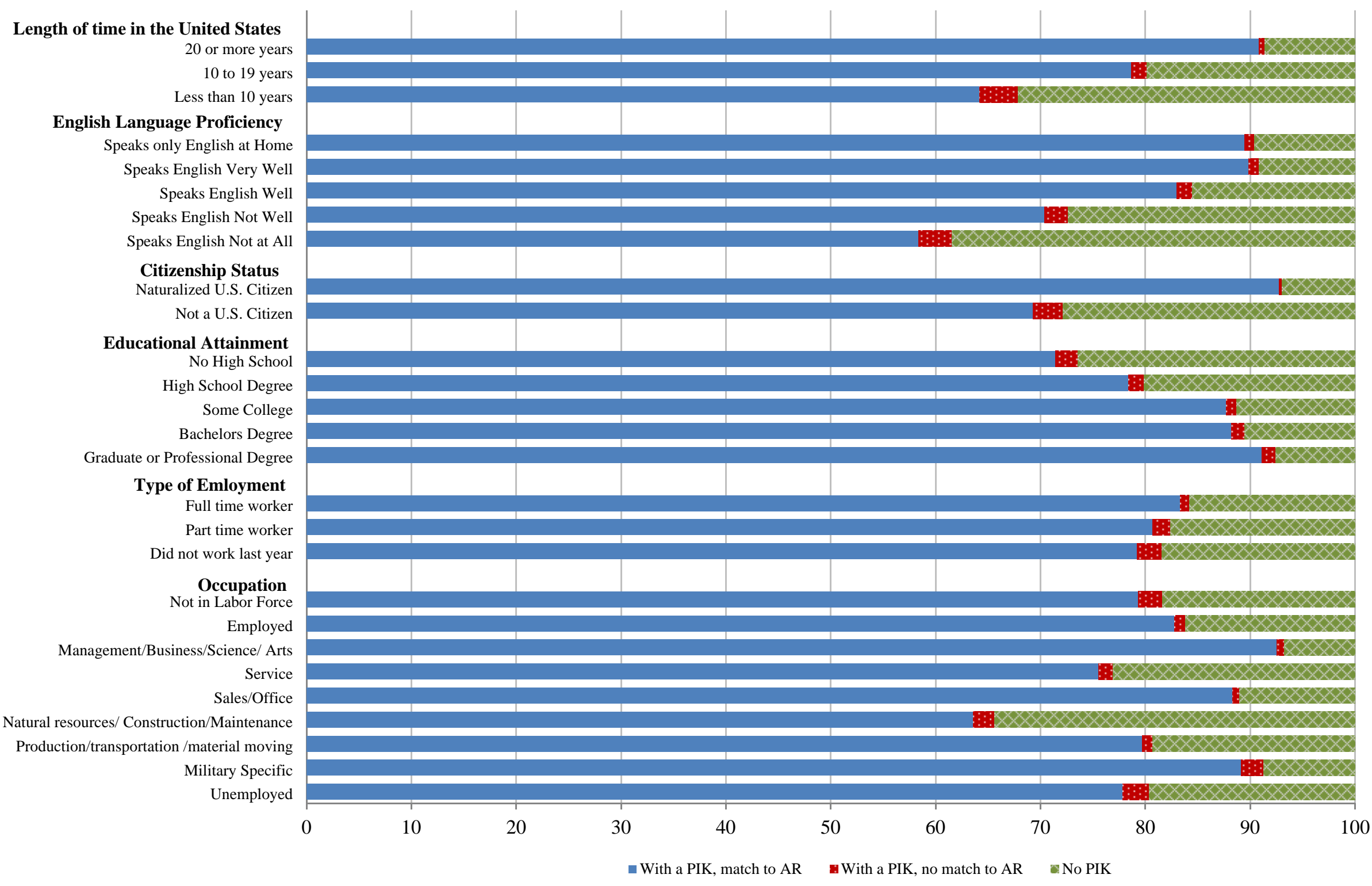


Figure 2, continued

Universe: Foreign-born ages 25 and older with non-allocated citizenship status

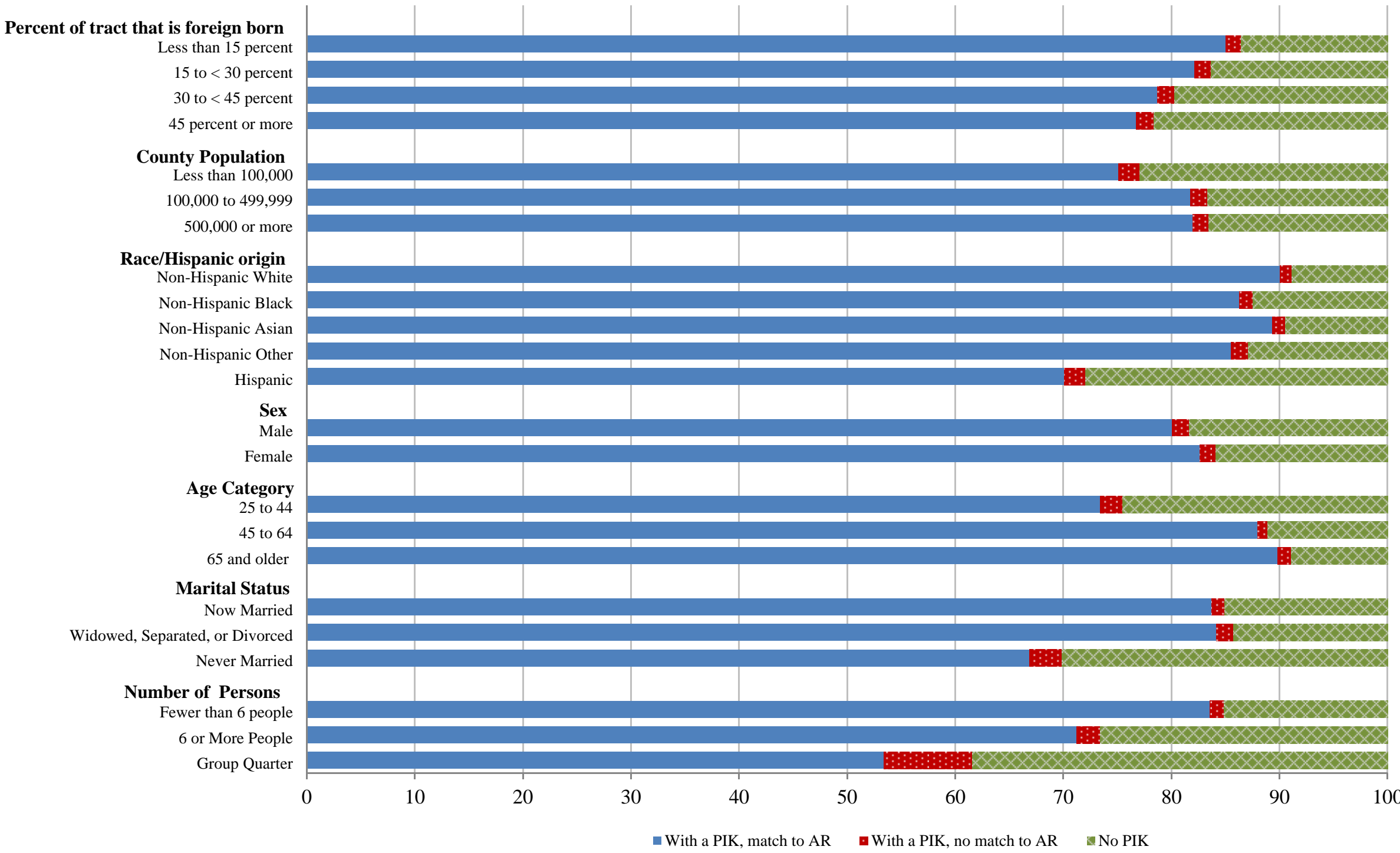

Source: 2006-2010 5-year American Community Survey data and 2010 Administrative Records data 
Appendix Table 1. PIK Assignment and Matching to Administrative Records by Nativity and ACS Survey Year

Universe: Persons ages 25 and older with non-allocated citizenship

\begin{tabular}{|c|c|c|c|c|c|c|}
\hline \multirow[t]{2}{*}{ Citizenship Status } & \multirow{2}{*}{$\begin{array}{l}\text { Total number } \\
\text { in sample }\end{array}$} & \multicolumn{2}{|c|}{ Assigned a PIK } & \multicolumn{3}{|c|}{ Match to AR } \\
\hline & & Number & Percent & Number & $\begin{array}{l}\text { Percent of } \\
\text { those with } \\
\text { PIKs }\end{array}$ & $\begin{array}{c}\text { Percent of } \\
\text { total } \\
\text { sample }\end{array}$ \\
\hline Foreign Born & $1,855,503$ & $1,539,032$ & 82.9 & $1,510,702$ & 98.2 & 81.4 \\
\hline 2006 & 366,251 & 299,220 & 81.7 & 294,274 & 98.3 & 80.3 \\
\hline 2007 & 366,373 & 298,230 & 81.4 & 294,230 & 98.7 & 80.3 \\
\hline 2008 & 363,996 & 296,543 & 81.5 & 293,311 & 98.9 & 80.6 \\
\hline 2009 & 375,282 & 301,175 & 80.3 & 298,441 & 99.1 & 79.5 \\
\hline 2010 & 383,601 & 343,864 & 89.6 & 330,446 & 96.1 & 86.1 \\
\hline Native Born & $13,361,203$ & $12,661,569$ & 94.8 & $12,615,210$ & 99.6 & 94.4 \\
\hline 2006 & 2,736,646 & 2,594,972 & 94.8 & 2,582,122 & 99.5 & 94.4 \\
\hline 2007 & $2,682,896$ & $2,536,644$ & 94.5 & $2,527,454$ & 99.6 & 94.2 \\
\hline 2008 & $2,659,961$ & $2,511,484$ & 94.4 & $2,503,948$ & 99.7 & 94.1 \\
\hline 2009 & $2,653,988$ & $2,503,568$ & 94.3 & $2,496,047$ & 99.7 & 94.0 \\
\hline 2010 & $2,627,712$ & $2,514,901$ & 95.7 & $2,505,639$ & 99.6 & 95.4 \\
\hline
\end{tabular}

Source: 2006-2010 5-year American Community Survey data and 2010 Administrative Records data 
Appendix Table 2. Percent of Persons Who Match to Administrative Records by Source File and Nativity

Universe: Persons ages 25 and older with non-allocated citizenship

\begin{tabular}{|l|r|r|}
\hline Administrative Records Source File & Foreign Born & \multicolumn{1}{|c|}{ Natives } \\
\hline Total in Sample & $1,539,032$ & $12,661,569$ \\
Percent in... & 98.2 & \\
Any administrative record (federal and third party data) & 96.3 & 99.6 \\
Federal data & 85.9 & 97.3 \\
IRS 1040 & 83.6 & 91.9 \\
IRS 1099 & 20.7 & 30.2 \\
Medicare Enrollment Database & 6.0 & 5.7 \\
HUDCHUMS & 3.9 & 2.3 \\
SSR & 1.7 & 1.3 \\
HUDPIC & 1.0 & 0.6 \\
HUDTRACS & 0.4 & 1.9 \\
Indian Health Service & 0.4 & 0.3 \\
SSS & 0.1 & 0.3 \\
Temporary Assistance for Needy Families & 88.4 & 98.3 \\
Third party data & 58.6 & 76.4 \\
File 1 & 75.5 & 90.4 \\
File 2 & 60.1 & 75.1 \\
File 3 & 27.2 & 32.6 \\
File 4 & 78.0 & 93.7 \\
File 5 & 11.6 & 13.4 \\
File 6 & 46.2 & 64.6 \\
File 7 & 74.7 & 90.2 \\
File 8 & &
\end{tabular}

Source: 2006-2010 5-year American Community Survey data and 2010 Administrative Records data 
Appendix Table 3. PIK Assignment and Administrative Records Coverage for the Foreign-born Population by Characteristic

Universe: Foreign-born ages 25 and older with non-allocated citizenship status

\begin{tabular}{|c|c|c|c|c|c|c|c|c|}
\hline \multirow[t]{2}{*}{ Characteristics } & \multicolumn{2}{|c|}{ Total } & \multicolumn{2}{|c|}{$\begin{array}{l}\text { With a PIK, match to } \\
\text { AR }\end{array}$} & \multicolumn{2}{|c|}{$\begin{array}{l}\text { With a PIK, no match } \\
\text { to AR }\end{array}$} & \multicolumn{2}{|c|}{ No PIK } \\
\hline & Number & Percent & Number & Percent & Number & Percent & Number & Percent \\
\hline \multicolumn{8}{|l|}{$\begin{array}{l}\text { Length of Residence in the U.S. } \\
20 \text { or more years }\end{array}$} & 8.6 \\
\hline 10 to 19 years & 496,728 & 100.0 & 390,765 & 78.7 & 7,208 & 1.5 & 98,755 & 19.9 \\
\hline Less than 10 years & 428,678 & 100.0 & 275,257 & 64.2 & 15,737 & 3.7 & 137,684 & 32.1 \\
\hline \multicolumn{9}{|l|}{ English Language Ability } \\
\hline Speaks only English at Home & 323,067 & 100.0 & 289,129 & 89.5 & 2,906 & 0.9 & 31,032 & 9.6 \\
\hline Speaks English Very Well & 578,574 & 100.0 & 519,823 & 89.8 & 5,713 & 1.0 & 53,038 & 9.2 \\
\hline Speaks English Well & 411,557 & 100.0 & 341,609 & 83.0 & 6,158 & 1.5 & 63,790 & 15.5 \\
\hline Speaks English Not Well & 361,993 & 100.0 & 254,858 & 70.4 & 7,880 & 2.2 & 99,255 & 27.4 \\
\hline Speaks English Not at All & 180,312 & 100.0 & 105,283 & 58.4 & 5,673 & 3.1 & 69,356 & 38.5 \\
\hline \multicolumn{9}{|l|}{ Citizenship } \\
\hline Naturalized U.S. Citizen & 959,075 & 100.0 & 889,422 & 92.7 & 2,843 & 0.3 & 66,810 & 7.0 \\
\hline Not a U.S. Citizen & 896,428 & 100.0 & 621,280 & 69.3 & 25,487 & 2.8 & 249,661 & 27.9 \\
\hline \multicolumn{9}{|l|}{ Educational Attainment } \\
\hline No High School & 554,149 & 100.0 & 395,849 & 71.4 & 11,925 & 2.2 & 146,375 & 26.4 \\
\hline High School Degree & 391,733 & 100.0 & 307,010 & 78.4 & 5,989 & 1.5 & 78,734 & 20.1 \\
\hline Some College & 350,455 & 100.0 & 307,433 & 87.7 & 3,488 & 1.0 & 39,534 & 11.3 \\
\hline Bachelors Degree & 317,597 & 100.0 & 280,242 & 88.2 & 3,871 & 1.2 & 33,484 & 10.5 \\
\hline Graduate or Professional Degree & 241,569 & 100.0 & 220,168 & 91.1 & 3,057 & 1.3 & 18,344 & 7.6 \\
\hline \multicolumn{9}{|l|}{ Type of Employment } \\
\hline Full time worker & 827,584 & 100.0 & 689,677 & 83.3 & 7,200 & 0.9 & 130,707 & 15.8 \\
\hline Part time worker & 449,379 & 100.0 & 362,601 & 80.7 & 7,542 & 1.7 & 79,236 & 17.6 \\
\hline Did not work last year & 578,540 & 100.0 & 458,424 & 79.2 & 13,588 & 2.3 & 106,528 & 18.4 \\
\hline \multicolumn{9}{|l|}{ Occupation } \\
\hline Not in Labor Force & 614,640 & 100.0 & 487,457 & 79.3 & 14,137 & 2.3 & 113,046 & 18.4 \\
\hline Employed & $1,158,279$ & 100.0 & 958,933 & 82.8 & 12,119 & 1.0 & 187,227 & 16.2 \\
\hline Management/Business/Science/ Arts & 391,718 & 100.0 & 362,518 & 92.5 & 2,869 & 0.7 & 26,331 & 6.7 \\
\hline Service & 243,284 & 100.0 & 183,754 & 75.5 & 3,386 & 1.4 & 56,144 & 23.1 \\
\hline Sales/Office & 205,001 & 100.0 & 181,100 & 88.3 & 1,312 & 0.6 & 22,589 & 11.0 \\
\hline Natural resources/ Construction/Maintenance & 138,128 & 100.0 & 87,810 & 63.6 & 2,801 & 2.0 & 47,517 & 34.4 \\
\hline Production/transportation /material moving & 178,884 & 100.0 & 142,624 & 79.7 & 1,725 & 1.0 & 34,535 & 19.3 \\
\hline Military Specific & 1,264 & 100.0 & 1,127 & 89.2 & 26 & 2.1 & 111 & 8.8 \\
\hline Unemployed & 82,584 & 100.0 & 64,312 & 77.9 & 2,074 & 2.5 & 16,198 & 19.6 \\
\hline
\end{tabular}


Appendix Table 3, continued

Universe: Foreign-born ages 25 and older with non-allocated citizenship status

\begin{tabular}{|c|c|c|c|c|c|c|c|c|}
\hline \multirow[t]{2}{*}{ Characteristics } & \multicolumn{2}{|c|}{ Total } & \multicolumn{2}{|c|}{ With a PIK, match to AR } & \multicolumn{2}{|c|}{$\begin{array}{l}\text { With a PIK, no match to } \\
\text { AR }\end{array}$} & \multicolumn{2}{|c|}{ No PIK } \\
\hline & Number & Percent & Number & Percent & Number & Percent & Number & Percent \\
\hline \\
\hline Less than 15 percent & 607,868 & 100.0 & 517,031 & 85.1 & 8,391 & 1.4 & 82,446 & 13.6 \\
\hline 15 to $<30$ percent & 522,175 & 100.0 & 428,749 & 82.1 & 8,231 & 1.6 & 85,195 & 16.3 \\
\hline 30 to $<45$ percent & 417,087 & 100.0 & 328,227 & 78.7 & 6,703 & 1.6 & 82,157 & 19.7 \\
\hline 45 percent or more & 308,373 & 100.0 & 236,695 & 76.8 & 5,005 & 1.6 & 66,673 & 21.6 \\
\hline \multicolumn{9}{|l|}{ County Population } \\
\hline Less than 100,000 & 136,939 & 100.0 & 102,813 & 75.1 & 2,717 & 2.0 & 31,409 & 22.9 \\
\hline 100,000 to 499,999 & 350,544 & 100.0 & 286,543 & 81.7 & 5,593 & 1.6 & 58,408 & 16.7 \\
\hline 500,000 or more & $1,368,020$ & 100.0 & $1,121,346$ & 82.0 & 20,020 & 1.5 & 226,654 & 16.6 \\
\hline \multicolumn{9}{|l|}{ Race and Hispanic origin } \\
\hline Non-Hispanic White & 453,835 & 100.0 & 408,565 & 90.0 & 5,132 & 1.1 & 40,138 & 8.8 \\
\hline Non-Hispanic Black & 120,682 & 100.0 & 104,099 & 86.3 & 1,561 & 1.3 & 15,022 & 12.4 \\
\hline Non-Hispanic Asian & 497,023 & 100.0 & 443,939 & 89.3 & 6,049 & 1.2 & 47,035 & 9.5 \\
\hline Non-Hispanic Other & 31,195 & 100.0 & 26,685 & 85.5 & 488 & 1.6 & 4,022 & 12.9 \\
\hline Hispanic & 752,768 & 100.0 & 527,414 & 70.1 & 15,100 & 2.0 & 210,254 & 27.9 \\
\hline \multicolumn{9}{|l|}{ Sex } \\
\hline Male & 877,269 & 100.0 & 702,418 & 80.1 & 13,934 & 1.6 & 160,917 & 18.3 \\
\hline Female & 978,234 & 100.0 & 808,284 & 82.6 & 14,396 & 1.5 & 155,554 & 15.9 \\
\hline \multicolumn{9}{|l|}{ Age Category } \\
\hline 25 to 44 & 874,218 & 100.0 & 641,782 & 73.4 & 18,059 & 2.1 & 214,377 & 24.5 \\
\hline 45 to 64 & 676,232 & 100.0 & 594,950 & 88.0 & 6,344 & 0.9 & 74,938 & 11.1 \\
\hline 65 and older & 305,053 & 100.0 & 273,970 & 89.8 & 3,927 & 1.3 & 27,156 & 8.9 \\
\hline \multicolumn{9}{|l|}{ Marital Status } \\
\hline Now Married & $1,288,592$ & 100.0 & $1,078,737$ & 83.7 & 15,722 & 1.2 & 194,133 & 15.1 \\
\hline Widowed, Separated, or Divorced & 305,935 & 100.0 & 257,520 & 84.2 & 4,788 & 1.6 & 43,627 & 14.3 \\
\hline Never Married & 260,976 & 100.0 & 174,445 & 66.8 & 7,820 & 3.0 & 78,711 & 30.2 \\
\hline \multicolumn{9}{|l|}{ Number of Persons in Household } \\
\hline Fewer than 6 people & $1,579,541$ & 100.0 & $1,319,984$ & 83.6 & 20,315 & 1.3 & 239,242 & 15.1 \\
\hline 6 or More People & 243,457 & 100.0 & 173,370 & 71.2 & 5,352 & 2.2 & 64,735 & 26.6 \\
\hline Group Quarter & 32,505 & 100.0 & 17,348 & 53.4 & 2,663 & 8.2 & 12,494 & 38.4 \\
\hline
\end{tabular}

Source: 2006-2010 5-year American Community Survey data and 2010 Administrative Records data 
Appendix Table 4. Odds of Being in Administrative Records for Each Survey Year

Universe: Foreign-born ages 25 and older with non-allocated citizenship

\begin{tabular}{|c|c|c|c|c|c|c|c|c|c|c|c|c|c|c|c|c|c|c|c|c|}
\hline \multirow{4}{*}{$\begin{array}{l}\text { Variable [reference category] } \\
\text { Length of Residence in the U.S. [20+ years] }\end{array}$} & \multicolumn{4}{|c|}{2006} & \multicolumn{4}{|c|}{2007} & \multicolumn{4}{|c|}{2008} & \multicolumn{4}{|c|}{2009} & \multicolumn{4}{|c|}{2010} \\
\hline & \multicolumn{2}{|c|}{ No PIK } & \multicolumn{2}{|c|}{$\begin{array}{c}\text { With a PIK, } \\
\text { no match to } \\
\text { AR }\end{array}$} & \multicolumn{2}{|c|}{ No PIK } & \multicolumn{2}{|c|}{$\begin{array}{c}\text { With a PIK, } \\
\text { no match to } \\
\text { AR }\end{array}$} & \multicolumn{2}{|c|}{ No PIK } & \multicolumn{2}{|c|}{$\begin{array}{c}\text { With a PIK, } \\
\text { no match to } \\
\text { AR }\end{array}$} & \multicolumn{2}{|c|}{ No PIK } & \multicolumn{2}{|c|}{$\begin{array}{c}\text { With a PIK, } \\
\text { no match to } \\
\text { AR }\end{array}$} & \multicolumn{2}{|c|}{ No PIK } & \multicolumn{2}{|c|}{$\begin{array}{c}\text { With a PIK, } \\
\text { no match to } \\
\text { AR }\end{array}$} \\
\hline & \multicolumn{4}{|c|}{$\begin{array}{c}\text { Reference category: } \\
\text { With a PIK, match to AR }\end{array}$} & \multicolumn{4}{|c|}{$\begin{array}{c}\text { Reference category: } \\
\text { With a PIK, match to AR }\end{array}$} & \multicolumn{4}{|c|}{$\begin{array}{c}\text { Reference category: } \\
\text { With a PIK, match to AR }\end{array}$} & \multicolumn{4}{|c|}{$\begin{array}{c}\text { Reference category: } \\
\text { With a PIK, match to AR }\end{array}$} & \multicolumn{4}{|c|}{$\begin{array}{c}\text { Reference category: } \\
\text { With a PIK, match to AR }\end{array}$} \\
\hline & & & & & & & & & & & & & & & & & & & & \\
\hline 10 to 19 years & 1.74 & $* * *$ & 1.45 & $* * *$ & 1.73 & $* * *$ & 1.78 & $* * *$ & 1.71 & $* * *$ & 1.79 & *** & 1.76 & *** & 2.12 & *** & 1.27 & $* * *$ & 2.19 & *** \\
\hline Less than 10 years & 3.35 & $* * *$ & 4.49 & $* * *$ & 3.00 & $* * *$ & 5.04 & $* * *$ & 2.73 & $* * *$ & 4.63 & *** & 2.83 & *** & 4.03 & *** & 2.11 & $* * *$ & 4.54 & *** \\
\hline \multicolumn{21}{|l|}{ English Language Ability [Speaks only English at home] } \\
\hline Speaks English Very Well & 0.73 & $* * *$ & 0.97 & $* * *$ & 0.74 & $* * *$ & 1.03 & ** & 0.75 & & 1.00 & ** & 0.76 & * & 1.12 & * & 0.75 & $* * *$ & 1.03 & $* * *$ \\
\hline Speaks English Well & 0.92 & $* * *$ & 1.25 & $* * *$ & 0.93 & $* * *$ & 1.20 & $* * *$ & 0.98 & $* * *$ & 1.20 & *** & 0.96 & $* * *$ & 1.20 & $* * *$ & 0.91 & $* * *$ & 1.26 & *** \\
\hline Speaks English Not Well & 1.36 & $* * *$ & 1.46 & $* * *$ & 1.36 & $* * *$ & 1.36 & $* * *$ & 1.36 & $* * *$ & 1.34 & *** & 1.33 & $* * *$ & 1.39 & *** & 1.27 & $* * *$ & 1.33 & $* * *$ \\
\hline Speaks English Not at All & 1.78 & $* * *$ & 1.75 & $* * *$ & 1.74 & $* * *$ & 1.68 & $* * *$ & 1.74 & $* * *$ & 1.41 & $* * *$ & 1.56 & $* * *$ & 1.49 & *** & 1.75 & $* * *$ & 1.41 & *** \\
\hline \multicolumn{21}{|l|}{ Citizenship [Naturalized U.S. Citizen] } \\
\hline Not a U.S. Citizen & 1.79 & $* * *$ & 3.36 & $* * *$ & 1.81 & $* * *$ & 3.79 & $* * *$ & 1.94 & $* * *$ & 5.37 & *** & 2.20 & *** & 6.14 & *** & 1.79 & $* * *$ & 9.51 & *** \\
\hline \multicolumn{21}{|l|}{ Educational Attainment [No High School Degree] } \\
\hline High School Degree & 1.09 & $* * *$ & 0.83 & $* * *$ & 1.06 & *** & 0.89 & $* * *$ & 1.03 & $* * *$ & 0.94 & *** & 1.03 & *** & 1.02 & *** & 1.05 & & 1.00 & *** \\
\hline Some College & 0.79 & $* * *$ & 0.69 & $* * *$ & 0.75 & $* * *$ & 0.65 & $* * *$ & 0.77 & $* * *$ & 0.77 & *** & 0.78 & & 0.76 & * & 0.83 & * & 0.88 & *** \\
\hline Bachelors Degree or Higher & 0.82 & $* * *$ & 0.94 & & 0.77 & $* * *$ & 0.89 & $* * *$ & 0.81 & $* * *$ & 1.05 & *** & 0.79 & *** & 0.89 & *** & 0.86 & $* * *$ & 1.01 & *** \\
\hline Type of Employment [Full time worker] & & & & & & & & & & & & & & & & & & & & \\
\hline Part time worker & 0.80 & $* * *$ & 1.21 & $* * *$ & 0.80 & $* * *$ & 1.26 & $* * *$ & 0.92 & $* * *$ & 1.25 & $* * *$ & 1.00 & $* * *$ & 1.15 & $* * *$ & 0.96 & $* * *$ & 1.42 & $* * *$ \\
\hline Did not work last year & 1.23 & $* * *$ & 1.87 & & 1.22 & $* * *$ & 1.65 & & 1.17 & $* * *$ & 1.60 & & 1.16 & $* * *$ & 1.64 & $* *$ & 1.05 & $* * *$ & 1.68 & \\
\hline Occupation [Not in Labor Force] & & & & & & & & & & & & & & & & & & & & \\
\hline Management/Business/Science/ Arts & 0.55 & & 0.97 & $* *$ & 0.58 & * & 0.65 & & 0.50 & $*$ & 0.38 & & 0.50 & ** & 0.34 & & 0.56 & $*$ & 0.42 & \\
\hline Service & 1.11 & $* * *$ & 0.84 & & 1.14 & $* * *$ & 0.66 & * & 1.01 & $* * *$ & 0.56 & *** & 0.93 & *** & 0.47 & *** & 0.91 & *** & 0.74 & *** \\
\hline Sales/Office & 0.76 & $* * *$ & 0.69 & $* * *$ & 0.80 & $* * *$ & 0.54 & $* * *$ & 0.69 & $* * *$ & 0.39 & $* * *$ & 0.65 & $* * *$ & 0.33 & $* * *$ & 0.71 & $* * *$ & 0.51 & $* * *$ \\
\hline Natural resources/Construction/Maintenance & 1.45 & $* * *$ & 1.12 & $* *$ & 1.51 & $* * *$ & 0.97 & * & 1.27 & $* * *$ & 0.84 & $* * *$ & 1.19 & $* * *$ & 0.74 & *** & 1.12 & $* * *$ & 0.97 & $* * *$ \\
\hline Production/transportation /material moving & 0.81 & $* * *$ & 0.65 & & 0.85 & $* * *$ & 0.46 & * & 0.73 & $* * *$ & 0.40 & & 0.68 & $* * *$ & 0.40 & & 0.64 & $* * *$ & 0.53 & * \\
\hline Military Specific & 0.63 & $* * *$ & 2.88 & $*$ & 0.57 & $* * *$ & 1.21 & & 0.59 & $* * *$ & 0.50 & * & 0.52 & $* * *$ & 0.71 & & 0.55 & $* * *$ & 1.09 & \\
\hline Unemployed & 0.87 & $* * *$ & 0.86 & & 0.88 & $* * *$ & 0.80 & & 0.79 & $* * *$ & 0.69 & $* *$ & 0.79 & $* * *$ & 0.71 & & 0.77 & $* * *$ & 0.87 & $*$ \\
\hline Log of household/personal income ${ }^{a}$ & 0.94 & *** & 0.95 & $* *$ & 0.93 & $* * *$ & 0.94 & & 0.93 & $* * *$ & 0.93 & * & 0.92 & $* * *$ & 0.93 & & 0.93 & $* * *$ & 0.92 & \\
\hline Median Income of Tract & 0.96 & & 0.96 & & 0.95 & $* *$ & 0.97 & & 0.95 & ** & 0.93 & $*$ & 0.96 & $* * *$ & 0.93 & & 0.97 & $* * *$ & 0.94 & \\
\hline
\end{tabular}

${ }^{a}$ The log of household income is used for individuals in housing units while the log of personal income is used for those living in group quarters. 


\section{Appendix Table 4, continued}

\begin{tabular}{|c|c|c|c|c|c|c|c|c|c|c|c|c|c|c|c|c|c|c|c|c|}
\hline \multirow{4}{*}{$\begin{array}{l}\text { Variable [reference category] } \\
\text { Percent of tract that is foreign born [Less than 15\%] }\end{array}$} & \multicolumn{4}{|c|}{2006} & \multicolumn{4}{|c|}{2007} & \multicolumn{4}{|c|}{2008} & \multicolumn{4}{|c|}{2009} & \multicolumn{4}{|c|}{2010} \\
\hline & \multicolumn{2}{|c|}{ No PIK } & \multicolumn{2}{|c|}{$\begin{array}{l}\text { With a PIK, } \\
\text { no match to } \\
\text { AR }\end{array}$} & \multicolumn{2}{|c|}{ No PIK } & \multicolumn{2}{|c|}{$\begin{array}{l}\text { With a PIK, } \\
\text { no match to } \\
\text { AR }\end{array}$} & \multicolumn{2}{|c|}{ No PIK } & \multicolumn{2}{|c|}{$\begin{array}{l}\text { With a PIK, } \\
\text { no match to } \\
\text { AR }\end{array}$} & \multicolumn{2}{|c|}{ No PIK } & \multicolumn{2}{|c|}{$\begin{array}{c}\text { With a PIK, } \\
\text { no match to } \\
\text { AR }\end{array}$} & \multicolumn{2}{|c|}{ No PIK } & \multicolumn{2}{|c|}{$\begin{array}{c}\text { With a PIK, } \\
\text { no match to } \\
\text { AR }\end{array}$} \\
\hline & \multicolumn{4}{|c|}{$\begin{array}{l}\text { Reference category: } \\
\text { With a PIK, match to AR }\end{array}$} & \multicolumn{4}{|c|}{$\begin{array}{l}\text { Reference category: } \\
\text { With a PIK, match to AR }\end{array}$} & \multicolumn{4}{|c|}{$\begin{array}{l}\text { Reference category: } \\
\text { With a PIK, match to AR }\end{array}$} & \multicolumn{4}{|c|}{$\begin{array}{l}\text { Reference category: } \\
\text { With a PIK, match to AR }\end{array}$} & \multicolumn{4}{|c|}{$\begin{array}{l}\text { Reference category: } \\
\text { With a PIK, match to AR }\end{array}$} \\
\hline & & & & & & & & & & & & & & & & & & & & \\
\hline 15 to $<30$ percent & 1.05 & $* * *$ & 1.07 & *** & 1.10 & $* * *$ & 1.10 & ** & 1.10 & $* * *$ & 1.09 & & 1.09 & $* * *$ & 1.08 & & 1.06 & $* * *$ & 1.07 & $* * *$ \\
\hline 30 to $<45$ percent & 1.11 & & 1.11 & *** & 1.16 & $* * *$ & 1.08 & * & 1.20 & $* * *$ & 1.15 & $* *$ & 1.17 & $* * *$ & 1.10 & $*$ & 1.20 & $* * *$ & 1.04 & $* * *$ \\
\hline 45 percent or more & 1.21 & $* * *$ & 1.07 & & 1.21 & $* *$ & 0.99 & & 1.34 & & 1.17 & & 1.30 & & 0.95 & * & 1.38 & & 1.07 & \\
\hline \multicolumn{21}{|l|}{ County Population [500,000 or more] } \\
\hline Less than 100,000 & 1.35 & $* * *$ & 1.20 & *** & 1.29 & $* * *$ & 1.11 & & 1.38 & $* * *$ & 1.16 & & 1.35 & $* * *$ & 1.12 & & 1.32 & $* * *$ & 1.02 & *** \\
\hline 100,000 to 499,999 & 1.02 & $* * *$ & 1.02 & $* * *$ & 1.04 & $* * *$ & 1.03 & $* * *$ & 1.04 & $* * *$ & 1.10 & & 1.06 & $* * *$ & 0.96 & ** & 1.08 & $* * *$ & 0.99 & $* * *$ \\
\hline \multicolumn{21}{|l|}{ Race [Non-Hispanic White] } \\
\hline Non-Hispanic Black & 0.99 & & 0.68 & *** & 1.01 & $* * *$ & 0.79 & $* * *$ & 0.98 & $* * *$ & 0.86 & $* * *$ & 0.97 & *** & 0.75 & $* * *$ & 0.96 & *** & 0.91 & *** \\
\hline Non-Hispanic Asian & 1.95 & $* * *$ & 0.84 & $* * *$ & 1.83 & $* * *$ & 0.86 & $* * *$ & 1.84 & $* * *$ & 1.02 & $* * *$ & 1.82 & $* * *$ & 1.09 & & 1.28 & $* * *$ & 1.37 & $* * *$ \\
\hline Non-Hispanic Other & 0.98 & $* * *$ & 0.84 & $* * *$ & 0.86 & $* * *$ & 0.90 & $* * *$ & 0.84 & $* * *$ & 0.86 & $* * *$ & 0.87 & $* * *$ & 0.85 & $* * *$ & 0.87 & $* * *$ & 0.86 & * \\
\hline Hispanic & 1.36 & $* * *$ & 0.95 & $* * *$ & 1.13 & $* * *$ & 0.99 & $* * *$ & 1.05 & $* * *$ & 0.98 & $* * *$ & 0.97 & $* * *$ & 0.64 & $* * *$ & 1.00 & $* * *$ & 1.13 & $* * *$ \\
\hline \multicolumn{21}{|l|}{ Sex [Male] } \\
\hline Female & 0.90 & $* * *$ & 0.81 & $* * *$ & 0.90 & $* * *$ & 0.78 & $* * *$ & 0.88 & $* * *$ & 0.83 & $* * *$ & 0.88 & $* * *$ & 0.72 & $* * *$ & 0.83 & $* * *$ & 0.83 & $* * *$ \\
\hline \multicolumn{21}{|l|}{ Age Category [25 to 44 ] } \\
\hline 45 to 64 & 0.62 & $* * *$ & 0.87 & $* * *$ & 0.60 & $* * *$ & 1.01 & $* * *$ & 0.60 & $* * *$ & 1.00 & $* * *$ & 0.59 & $* * *$ & 0.93 & $* * *$ & 0.75 & $* * *$ & 0.69 & $* * *$ \\
\hline 65 and older & 0.48 & $* * *$ & 1.88 & $* * *$ & 0.45 & $* * *$ & 1.47 & $* * *$ & 0.44 & $* * *$ & 1.11 & $* * *$ & 0.40 & $* * *$ & 0.79 & $* * *$ & 0.60 & $* * *$ & 0.47 & $* * *$ \\
\hline Marital Status [Now Married] & & & & & & & & & & & & & & & & & & & & \\
\hline Widowed, Separated, or Divorced & 1.23 & $* * *$ & 2.00 & $* * *$ & 1.19 & $* * *$ & 1.78 & $* * *$ & 1.14 & $* * *$ & 1.69 & $* * *$ & 1.16 & $* * *$ & 1.45 & $* * *$ & 1.32 & $* * *$ & 1.20 & $* * *$ \\
\hline Never Married & 1.76 & $* * *$ & 2.44 & $* * *$ & 1.69 & $* * *$ & 2.41 & $* * *$ & 1.72 & $* * *$ & 2.34 & $* * *$ & 1.75 & $* * *$ & 2.57 & $* * *$ & 2.08 & $* * *$ & 1.70 & $* * *$ \\
\hline Number of Persons in Household [Fewer than 6 peo & & & & & & & & & & & & & & & & & & & & \\
\hline 6 or More People & 1.26 & $* * *$ & 1.24 & *** & 1.24 & $* * *$ & 1.27 & $* * *$ & 1.22 & $* * *$ & 1.34 & $* * *$ & 1.33 & $* * *$ & 1.34 & $* * *$ & 1.25 & $* * *$ & 1.30 & $* * *$ \\
\hline Group Quarter & 2.16 & $* * *$ & 7.67 & $* * *$ & 2.14 & $* * *$ & 6.86 & $* * *$ & 1.84 & $* * *$ & 4.68 & $* * *$ & 1.42 & $* * *$ & 3.89 & $* * *$ & 1.52 & $* * *$ & 1.14 & $* * *$ \\
\hline Sample size & 67, & & & 4,946 & & 8,143 & & 4,000 & & 7,453 & & 3,232 & & 4,107 & & 2,734 & & 9,737 & & 3,418 \\
\hline
\end{tabular}

Source: 2006-2010 5-year American Community Survey data and 2010 Administrative Records Data ${ }^{*} \mathrm{p}<=.05,{ }^{*} \mathrm{p}<=.01, * * * \mathrm{p}<=.001$ 